Summer 7-1-2020

\title{
The link among board characteristics, corporate social responsibility performance, and financial performance: Evidence from the hospitality and tourism industry
}

Ali Uyar

Merve Kilic

Mehmet Ali Koseoglu

Cemil Kuzey

Murray State University, ckuzey@murraystate.edu

Abdullah S. Karaman

Follow this and additional works at: https://digitalcommons.murraystate.edu/faculty

Part of the Business Analytics Commons, Business Intelligence Commons, and the Hospitality Administration and Management Commons

\section{Recommended Citation}

This is an Accepted Manuscript of an article published by Elsevier in Tourism Management Perspectives on July 2020, available online: https://doi.org/10.1016/j.tmp.2020.100714

This Journal Article is brought to you for free and open access by Murray State's Digital Commons. It has been accepted for inclusion in Faculty \& Staff Research and Creative Activity by an authorized administrator of Murray State's Digital Commons. For more information, please contact msu.digitalcommons@murraystate.edu. 


\title{
The link among board characteristics, corporate social responsibility performance, and financial performance: Evidence from the hospitality and tourism industry
}

\begin{abstract}
The aim of this study is twofold: to explore whether board characteristics (i.e. a sustainability committee, board independence, board diversity, and board diligence) lead to greater corporate social responsibility (CSR) performance, and to test whether CSR performance enhances firms' financial performance in the hospitality and tourism (H\&T) industry. Data were collected from the Thomson Reuters Eikon database for the H\&T firms listed there between 2011 and 2018. We employed panel data analysis, after which we ran robustness tests. The results indicated that having a CSR committee and female directors on the board are robust factors driving firms to show superior CSR performance in all dimensions, including environmental, social, and governance (ESG). Independent directors and directors' diligence selectively enhance the overall CSR score and individual pillars of CSR. Investigating the relationship between CSR performance and firms' financial performance did not produce a significant outcome. The findings propose a straightforward roadmap for H\&T firms and policymakers to identify characteristics of CSRfriendly boards.
\end{abstract}

Keywords: CSR; ESG; social; environmental; governance; firm performance

\section{Introduction}

In the hospitality and tourism (H\&T) industry, the basis of the tourism product is the social, cultural, and natural capital of a destination (Moneva, Bonilla-Priego, \& Ortas, 2019). While the H\&T industry brings economic and social benefits to destinations, it is criticized for its negative impacts on societies and the natural environment, such as climate change, biodiversity loss, air and noise pollution, and waste generation (de Grosbois, 2012; Scott, Peeters, \& Gossling, 2010). Criticisms also arise due to certain sectors within the H\&T industry, such as fast-food restaurants that cause obesity and casinos that provide opportunities for gambling. This stimulates firms in these sectors to focus on corporate social responsibility (CSR) to decrease reputational costs (Rhou \& Singal, 2020). This places greater pressure on H\&T firms to behave responsibly and to undertake CSR practices, and thus makes it relevant to study CSR-related issues in the H\&T context. 
There is a growing body of green governance literature which implies that boards should be formed in such a way that they put environmental and social concerns high on the priority list of the corporate agenda (Mahmood \& Orazalin, 2017; Post, Rahman, \& Rubow, 2011). In particular, a board's composition, activity, and structure may be influential in fostering firms' CSR commitment. The resource dependence theory (Hillman \& Dalziel, 2003; Pfeffer \& Salancik, 1978) and upper echelons theory (Hambrick, 2007; Hambrick \& Mason, 1984) indicate that board characteristics (BC) play crucial roles in the formulation and implementation of firms' strategies. Abundant studies have addressed the links between BC and CSR practices, particularly regarding environment-focused firm practices (Bose, Khan, Rashid, \& Islam, 2018; Post et al., 2011; Rodriguez-Fernandez, 2016; Wang \& Sarkis, 2017). These studies do not deliver a clear message on the link between $\mathrm{BC}$ - such as board gender diversity, board meeting attendance, non-executive board members, and CSR/sustainability committee - and CSR performance (CSRP), including environmental, social, and governance performance. Negative impacts of H\&T firms' operations on societies and environments justify studying the business case for CSR in the H\&T context (Rhou \& Singal, 2020). However, few studies have examined how CSRP influences financial performance related to value-based performance and profitability in the H\&T industry; those that have mostly documented ambiguous or contradictory findings (Benavides-Velasco, QuintanaGarcía, \& Marchante-Lara, 2014; Franco, Caroli, Cappa, \& Del Chiappa, 2019; GonzálezRodríguez, Martín-Samper, Köseoglu, \& Okumus 2019; Kang, Lee, \& Huh, 2010; Moneva et al., 2019; Singal, 2014; Theodoulidis, Diaz, Crotto, \& Rancati, 2017). Therefore, the primary purpose of this study is to investigate how firms' BC influences their CSRP, and to clarify the relationship between CSRP and firms' financial performance.

To achieve the purpose of this study, we considered firms operating in the H\&T industry for three reasons. First, in many countries, the H\&T industry has a large influence on the social, economic, and political environments as an export sector (UNWTO, 2016). Second, the structure of the H\&T industry or H\&T firms is heavily related to the boundaries of several other industries (Okumus, Altinay, \& Chathoth, 2010). Third, according to Singal (2015), the H\&T industry shows higher leverage, risk, capital intensity, and competitive rivalry than other industries. These reasons imply that H\&T firms face challenges or opportunities in formulating and implementing CSR strategies designed by firms' board members. Consequently, BC in H\&T firms should identify and design efficient CSR practices that affect firms' financial performance. Several studies link BC to 
H\&T firms' performance (Mu Yeh, 2013, 2018, 2019), but the links between BC, CSRP, and financial performance in H\&T firms are not clear (Guillet \& Mattila, 2010). Although Ghaderi, Mirzapour, Henderson, and Richardson $(2019)^{1}$ examined the association between CSRP and hotel performance, they used multiple proxies for performance, including financial, reputation, productivity, and innovation performance, which does not allow for an assessment of the direct association between CSRP and financial performance. Therefore, the findings of this study represent a significant contribution to the H\&T literature.

The data for the study were collected from the Thomson Reuters Eikon database regarding H\&T firms listed between 2011 and 2018. The cross-country nature of the data used in the study improves the generalizability of the findings around the world. The data were subject to panel data regression analysis with fixed effects estimators to test the hypothesized relationships. After running baseline results, several robustness checks were run to verify the outputs.

After a literature review of CSR in the H\&T industry, the study establishes a theoretical background and develops the hypotheses. Next, we discuss the research methodology employed in this study. Finally, we present and discuss the findings, provide theoretical and practical implications, and make suggestions for future studies.

\section{Literature Review and Hypothesis Development}

\subsection{Corporate Social Responsibility in the Hospitality and Tourism Industry}

Although initially CSR research in the H\&T sector received less attention than in industries that are seen as heavy polluters (i.e. chemicals, manufacturing, and mining), growing concerns about the H\&T industry's negative social and environmental impacts have led researchers to pay increasing attention to CSR issues in that industry (de Grosbois, 2012) ${ }^{2}$. However, CSR research in the H\&T industry is still slow (Mihalic, 2016) and minor compared to the research undertaken in heavy polluter industries (Moyeen, Kamal, \& Yousuf, 2019). While a strand of research has studied the extent of CSR efforts implemented by H\&T firms (Khatter, McGrath, Pyke, White, \& Lockstone-Binney, 2019; Kucukusta, Mak, \& Chan, 2013; Suárez-Cebador, Rubio-Romero, Pinto-Contreiras, \& Gemar, 2018; Tsai, Hsu, Chen, Lin, \& Chen, 2010), a further strand has

\footnotetext{
${ }^{1}$ The study was a country-specific study based on a questionnaire survey conducted in Iran.

${ }^{2}$ Please see the papers of Coles et al. (2013), Font and Lynes (2018), Iyer and Jarvis (2019), and Moyeen et al. (2019) for an extensive literature review on CSR in the H\&T industry.
} 
examined the communication of such efforts (de Grosbois, 2012). The association between corporate governance and CSR practices in the H\&T industry has not yet been examined. This study addresses this lack of research by exploring whether and how BC are associated with CSRP in the H\&T industry.

A stream of papers have analyzed the impact of CSR practices on various aspects of H\&T firms' organizational performance, such as customer loyalty (Gürlek, Düzgün, \& Meydan Uygur, 2017), employees' work engagement (Gürlek \& Tuna, 2019), organization citizenship behavior (He, Zhang, \& Morrison, 2019), reputation (Ghaderi et al., 2019), and productivity (Ghaderi et al., 2019). Nevertheless, a limited number of studies have examined the impact of CSR practices on firms' financial performance in the H\&T industry (Benavides-Velasco et al., 2014; Franco et al., 2019; González-Rodríguez et al., 2019; Kang et al., 2010; Singal, 2014; Theodoulidis et al., 2017) $)^{3}$. Further, most of these studies have focused on a particular sub-industry of the H\&T industry, such as hotels (Benavides-Velasco et al., 2014; González-Rodríguez et al., 2019) or a single country (Benavides-Velasco et al., 2014; González-Rodríguez et al., 2019; Singal, 2014). This study adds to the literature by examining the relationship between CSRP and financial performance in the H\&T industry, covering the sub-industries cruise lines, motels \& hotels, gaming \& casinos, recreation industries \& leisure, and bars \& restaurants on a global scale. By doing so, this study provides more generalizable findings on the relationship between CSRP and financial performance in the H\&T context.

\subsection{Board Characteristics and Corporate Social Responsibility Performance}

This study examines the association between BC and CSRP using the lenses of resource dependence and upper echelons theories. A board of directors has two major functions: monitoring (control role) and resource provision (service role) (Hillman \& Dalziel, 2003). First, monitoring managers is important to ensure that their decisions and actions are in line with shareholders' interests, and other stakeholders' expectations and interests (Godos-Díez, Cabeza-García, AlonsoMartínez, \& Fernández-Gago, 2018). In this context, a board of directors acts as an effective monitoring mechanism for protecting stakeholders' interests (Pucheta-Martínez \& GallegoÁlvarez, 2019), ensuring the fulfillment of ethical, social, and environmental responsibilities (García Martín \& Herrero, 2019), and encouraging the management team to get involved in CSR

\footnotetext{
${ }^{3}$ Please see the paper of Rhou and Singal (2020) for a comprehensive review in the domain.
} 
activities (Pucheta-Martínez \& Gallego-Álvarez, 2019). Second, the resource dependence theory refers to board capital, consisting of human capital (i.e. experience, expertise, knowledge, and skills) and relational capital (i.e. network of ties to the external environment and stakeholders) (Hillman \& Dalziel, 2003). The resource-based view defines societal demands as part of the external environment (Amran, Lee, \& Devi, 2014). This view states that knowledge provided by directors about the external environment and stakeholders may help firms to effectively address CSR issues and perform better CSR activities (Godos-Díez et al., 2018). Further, the upper echelons theory argues that directors' and executives' decisions and decision-making processes reflect their experience, knowledge, personalities, skills, and values (Hambrick, 2007). These upper echelon members with their diverse characteristics affect firms' strategic decisions related to both financial and non-financial issues (Hambrick \& Mason, 1984; Shahab, Ntim, Chengang, Ullah, \& Fosu, 2018), and thus their CSRP.

To better understand the relationship between $\mathrm{BC}$ and CSRP, we considered four BC-board gender diversity, board diligence, non-executive board members, and CSR/sustainability committee - and four CSRP indicators - composite $\mathrm{ESG}^{4}$ score and its three sub-dimensions: environmental, social, and governance indicators. Examining these indicators is effective because they are used alone or in pairs to identify relationships between them in the manufacturing industry (Buchanan, Cao, \& Chen, 2018; Chen, Feldmann, \& Tang, 2015; García-Sánchez, Hussain, \& Martínez-Ferrero, 2019; Liao, Luo, \& Tang, 2015; McGuinness, Vieito, \& Wang, 2017; Wang \& Sarkis, 2017). In this study, we consider all the BC simultaneously, as components of the model seen in Figure 1.

\section{INSERT FIGURE 1 HERE}

This proposed conceptual model addresses linkages between BC and CSRP and, subsequently, CSRP and the financial performance of firms. The first four constructs under BC are included when considering resource dependence and upper echelons theories because they may drive CSRP and the financial performance of firms.

\subsubsection{Board Gender Diversity and Corporate Social Responsibility Performance}

\footnotetext{
${ }^{4}$ For this research, environmental, social, and governance (ESG) scores are used to measure the CSRP of H\&T firms.
} 
Board gender diversity is the first component of BC in the model. According to the resourcebased view, female directors enhance a board's monitoring ability by bringing different perspectives, knowledge, skills, and experiences to the boardroom (Adams \& Ferreira, 2009; Hillman, Shropshire, \& Cannella, 2007). This view suggests that female directors who serve as providers of human and relational capital improve a firm's CSRP by building relations with the external environment and all stakeholders (Mallin \& Michelon, 2011). From the perspective of upper echelons theory, directors with different knowledge, skills, and expertise may influence a firm's strategic decisions, and thus improve its financial and non-financial performance (Shahab et al., 2018). Research has shown that female directors tend to have more ethical and social abilities than their male counterparts and are more likely to behave socially and environmentally responsibly (Pucheta-Martínez \& Gallego-Álvarez, 2019). In this context, females in upper echelons can urge the board to make relevant decisions concerning CSR issues and encourage management to undertake CSR-related activities, which lead to greater CSRP. Empirically, Mallin and Michelon (2011) found a significant positive relationship between gender diversity on the board and employee relations and human rights performance. Likewise, Bear, Rahman, and Post (2010) showed that the number of women board members positively influences CSR strength ratings in the firms included in Fortune's 2009 Most Admired List. Further, García Martín and Herrero (2019), Hussain, Rigoni, and Orij (2018), Orazalin and Baydauletov (2020), and Post, Rahman, and McQuillen (2015) determined that the presence of female directors improves firms' performance related to CSR. In line with theoretical discussions and prior empirical findings, the following hypothesis $(\mathrm{H})$ is proposed:

H1: Gender diversity on H\&T firms' boards is positively associated with (a) ESG performance,

(b) environmental performance, (c) social performance, and (d) governance performance as components of CSRP.

\subsubsection{Board Diligence and Corporate Social Responsibility Performance}

The second component of BC selected in this study is the average attendance at board meetings, due to its effect on the strategy formulation and implementation process (Chou, Chung, \& Yin, 2013; Gafoor, Mariappan, \& Thyagarajan, 2018; Lin, Yeh, \& Yang, 2014). There are two opposing views regarding the link between board activity and firms' performance. On the one hand, the board meeting frequency is considered to be a sign of board effectiveness, which would 
lead to better corporate management control (Lipton \& Lorsch, 1992) and improve firms' performance in terms of financial and non-financial outcomes. On the other hand, a high number of meetings may reflect a board's ineffectiveness, and thus would be negatively associated with firms' performance.

Several studies (see Eluyela, Akintimehin, Okere, Ozordi, Osuma, Ilogho, \& Oladipo, 2018; Mishra \& Mohanty, 2014; Vafeas, 1999; Webb, 2004) indicated a relationship between the number of board meetings and firms' performance. Further, Burke, Hoitash, and Hoitash (2019) documented that the meeting frequency of sustainability committees positively impacts their effectiveness. However, the connection between CSRP and board diligence has not been investigated, with a few exceptions (Godos-Díez et al., 2018; Hussain et al., 2018). While Hussain et al. (2018) determined that frequent board meetings enhance the social performance of firms, Godos-Díez et al. (2018) failed to find a significant association between the number of board meetings and firms' CSR engagement. Since the number of meetings is expected to play a vital role in the development of CSR strategies, the following hypothesis is formulated:

$\mathrm{H} 2$ : Board diligence (i.e. the average board meeting attendance rate) in H\&T firms' boards is positively associated with (a) ESG performance, (b) environmental performance, (c) social performance, and (d) governance performance as components of CSRP.

\subsubsection{Non-Executive Board Members and Corporate Social Responsibility Performance}

The presence of non-executive board members on a firm's board is the third component of BC in the model. This characteristic concern whether there are non-executive directors on a firm's board; the term can be used interchangeably with independent directors (Kiliç, Kuzey, \& Uyar, 2015). Non-executive board members may ensure board independence from management, and improve the board's objectivity and its ability to represent multiple perspectives (Michelon \& Parbonetti, 2012). Board independence is expected to be positively associated with CSRP, since independent directors are relatively less subjected to pressure from managers and shareholders than other directors (Hussain et al., 2018) and their mission is to align the interests of shareholders, managers, and stakeholders (Fernandes, 2008; Hoitash, 2011; Lee, Rosenstein, Rangan, \& Davidson, 1992). Further, independent directors may successfully address stakeholders' interests by providing new resources and insights and using their contacts and business expertise (Post et al., 2015). Empirically, Hussain et al. (2018), Mallin and Michelon (2011), and Post et al. (2015) 
documented that a higher proportion of independent directors leads to a greater level of CSRP. Therefore, the following hypothesis is suggested:

H3: The presence of non-executive board members on H\&T firms' boards is positively associated with (a) ESG performance, (b) environmental performance, (c) social performance, and (d) governance performance as components of CSRP.

\subsubsection{Corporate Social Responsibility/Sustainability Committee and Corporate Social} Responsibility Performance

The last component of $\mathrm{BC}$ in the model is CSR/sustainability committees, referring to the existence of a sub-committee dedicated to CSR-related issues operating within the firm's board structure. A firm can implement various activities and programs at the board level to better manage relations with stakeholders and deal with social and environmental issues, such as establishing a particular CSR/sustainability committee (Michelon \& Parbonetti, 2012). The creation of $\mathrm{CSR} /$ sustainability committees may reflect a firm's willingness to engage in CSR practices to meet stakeholders' needs (Mallin \& Michelon, 2011). According to resource dependence theory, a $\mathrm{CSR} /$ sustainability committee can be regarded as an important human capital resource element that supervises all issues related to CSR activities (Pucheta-Martínez \& Gallego-Álvarez, 2019) and promotes socially and environmentally responsible management (Amran et al., 2014). In terms of empirical evidence, García Martín and Herrero (2019), Godos-Díez et al. (2018), Hussain et al. (2018), and Mallin and Michelon (2011) showed that the existence of a board sub-committee responsible for CSR issues positively impacted firms' CSR engagement. In line with theoretical discussions and prior empirical findings, the following hypothesis is developed:

H4: The existence of a sub-committee responsible for CSR activities reporting to H\&T firms' boards is positively associated with (a) ESG performance, (b) environmental performance, (c) social performance, and (d) governance performance as components of CSRP.

\subsubsection{Corporate Social Responsibility Performance and Financial Performance}

As seen in Figure 1, our model tests the impact of CSRP measured with an aggregate ESG score as well as its three dimensions (i.e. environmental, social, and governance) on the financial performance of H\&T firms. First, the environmental dimension of CSRP has a crucial role in the case of the H\&T sector, because it is increasingly linked to the quality of the tourism product 
(Benavides-Velasco et al., 2014). Environment-related practices can provide financial benefits to H\&T firms, for example, through saving energy and water and being highly valued by stakeholders (Suárez-Cebador et al., 2018). Kucukusta et al. (2013) determined that environmental aspects of CSR are one of the most important factors impacting willingness to pay, preference to stay, and brand image in the hotel industry. Second, the social dimension of CSRP, covering practices such as supporting social projects in the local area, implementing equality and non-discriminatory hiring policies in the workplace, supplying healthy and certified local food, and adapting facilities for disabled customers, can give hotel firms competitive advantages (Tsai et al., 2010). Regarding the social dimension, Ghaderi et al. (2019) argued that support for community and society well-being and the protection of local culture and heritage may significantly improve hotels' financial performance, reputation, productivity, and innovation capabilities. Third, good corporate governance practices ensure effective monitoring by the board and give companies the ability to address stakeholders' demands properly (Moneva et al., 2019). A proper response to stakeholders' expectations and demands enhances corporate reputation (Ghaderi et al., 2019) and legitimacy (Cullinan, Mahoney, \& Roush, 2018), resulting in greater financial performance. Consequently, CSR practices in terms of environment, society, and governance are expected to lead to better financial results in the H\&T sector.

The literature provides mixed results about how CSR activities influence firms' performance (Jamali \& Karam, 2018). McWilliams and Siegel (2000) found that CSR's impact on financial performance is neutral. Many studies (Bird, Hall, Momentè, \& Reggiani, 2007; Orlitzky, Schmidt, \& Rynes, 2003; Saeidi, Sofian, Saeidi, Saeidi, \& Saaeidi, 2015; Wang \& Sarkis, 2017) demonstrated a positive relationship between CSR activities and financial performance, while other studies (Lima Crisóstomo, de Souza Freire, \& Cortes de Vasconcellos, 2011) indicated a negative relationship. Wang and Sarkis (2017) clarified the link between CSRP and financial performance by considering value-based performance (Tobin Q) and profitability (return on assets [ROA]) via a sample of 1,980 firm-year observations from the top 500 green companies in the United States over 2009-2013. With a particular focus on the H\&T industry, a number of studies (Benavides-Velasco et al., 2014; Boluk, 2013; Ghaderi et al., 2019; Qu, 2014; Zhu, 2013) examined the influence of CSR activities on financial performance and documented that greater CSRP results in better financial outcomes. Therefore, the last hypothesis is: 
H5: CSRP components (a) ESG performance, (b) environmental performance, (c) social performance, and (d) governance performance in H\&T firms are positively associated with the financial performance of firms measured via (a) value-based performance (Tobin Q) and (b) profitability (ROA).

\section{Research Methodology}

\subsection{Sample}

The data for this study were collected from the Thomson Reuters Eikon (hereafter Eikon) database for H\&T firms listed between 2011 and 2018. The Eikon database contains some of the broadest and deepest firm-level financial analysis data accessible. It provides industry-leading data including financial news, stock price data, financial ratios, BC, board meeting attendance, CSR committees, ESG scores, and company fundamentals (corresponding to $99 \%$ of the global market capitalization extending over 150 countries and more than 72,000 listed companies), among others. The Eikon database also allows for the retrieval of ESG-related data on thousands of firms (Refinitiv, 2019a).

The Eikon database classifies firms into 10 main economic sectors, 28 business sectors, and a further 54 industry groups according to their activities. It lists H\&T as one of the industry groups, including cruise lines, motels \& hotels, gaming \& casinos, recreation industries \& leisure, and bars \& restaurants (Refinitiv, 2019b). Hence, all data for these industries were retrieved from the Eikon database. Prior studies using financial and ESG data as well as BC data retrieved from the Eikon database include Arayssi, Jizi, and Tabaja (2019), Dell'Atti, Trotta, Iannuzzi, and Demaria (2017), Gallego-Álvarez and Pucheta-Martínez (2020), and Helfaya and Moussa (2017). The BC (including board gender diversity, board diligence, board independence, CSR committee, and board size), ownership-related data (free float percentage), and financial control variables (such as firm size, leverage, and profitability) were selected based on De Beelde and Tuybens (2015), Liao, Lin, and Zhang (2018), and Uyar, Karaman, and Kilic (2020).

Dell'Atti et al. (2017), Luo, Wang, Raithel, and Zheng (2015), and Wang, Hsieh, and Sarkis (2018) used ESG scores as proxies for CSRP. The ESG scores range between 0 (worst) and 100 (best) (Dell'Atti et al., 2017). The Eikon database's ESG scores are computed from firm-reported data and are tailored to openly and objectively evaluate a firm's ESG performance, commitment, 
and potency across 10 matters: innovation, emissions, resource use, human rights, workforce, management, product responsibility, CSR strategy, shareholders, and community. ESG data are available for more than 7,000 companies going back to 2002; however, a smaller number of firms' ESG scores are disclosed in earlier years. ESG scores (as used in this study) enhance and replace the previously well-known Asset $4{ }^{\circledR}$ Equal Weighted Ratings. The ESG data correspond to $70 \%$ of worldwide market capitalization, including 178 critical ESG metrics.

The Eikon's ESG performance percentile ranking methodology calculates relative ranks. The methodology calculates 10 category scores (for resource use, emissions, etc.) based on the number of companies that have (a) a score, (b) a poorer score than the current firm, and (c) the same score (Refinitiv, 2020). The 10 category scores are then added up to environmental, social, and corporate governance scores and the final ESG score ${ }^{5}$. Category scores are the sum of (equally weighted) pertinent individual critical ESG indicators (Refinitiv, 2020). The Environment Pillar score assesses firms' performance in evading environmental risks and caring for the environment under three categories: emissions, resource use, and innovation scores (Refinitiv, 2020). The Social Pillar score evaluates how firms maintain diversity and equal opportunity within the workforce, comply with human rights, promote community development, and deliver goods and services in a safe and healthy way (Refinitiv, 2020). The Governance Pillar score measures firm management's ability and success in communicating firms' CSR practices with stakeholders, treating shareholders equally, and implementing corporate governance principles (Refinitiv, 2020).

The initial sample size of the research data set was 940 firm-year records. Data preprocessing is a crucial step before further analysis. Therefore, the raw data set was subjected to multiple imputation and outlier detection. Initially, the variables with missing values were imputed. Furthermore, outliers were detected using a minimum covariance determinant (MCD) estimator to robustify the Mahalanobis distances (Verardi \& Dehon, 2010). Following the MCD multivariate outlier detection approach, 20 extreme firm-year records were removed from the data set. The final sample size was 920 firm-year records. Additionally, the leverage control variable had a high range, with a high dispersion around the mean value. Therefore, it was winsorized in both tails at one percent to replace the extreme values in both tails.

\footnotetext{
${ }^{5}$ Refinitiv (2020) includes the detailed ESG percentile scoring methodology.
} 
The sample included 172 firms. The number of firms within each year in the panel data is not stable. There are 78 firms in 2011, 88 firms in 2012, 90 firms in 2013, 96 firms in 2014, 111 firms in 2015, 138 firms in 2016, 154 firms in 2017, and 165 firms in 2018. The final sample was 920 firm-year records ${ }^{6}$.

\subsection{Variables}

We adopted five sets of variables for the dimensions in this study: CSRP, firm performance, BC, ownership structure, and financial variables. First, CSRP was proxied by the composite ESG score, as well as its three individual scores (Eliwa, Aboud, \& Saleh, 2019; Garcia, Mendes-DaSilva, \& Orsato, 2017). Second, firm performance was assessed by two well-known and frequently used financial performance indicators, namely Tobin Q and ROA (Inoue \& Lee, 2011; Kang et al., 2010, 2010; Rhou, Singal, \& Koh, 2016; Wang \& Sarkis, 2017). While Tobin Q is a market-based performance indicator, ROA is an accounting-based one. Tobin $\mathrm{Q}$ takes into account the market value of firms on the stock exchange. ROA considers net income and total assets, which are both drawn from financial statements (i.e. income statement and balance sheet). Therefore, these two measures assess different aspects of firm performance. Within the framework of this study, while Tobin Q assesses whether shareholders attach value to firms' CSRP, ROA measures whether CSRP enhances firm profitability through improving sales as well as controlling costs. Third, BC were measured by board diversity, board diligence, board independence, having a CSR committee at the board level, board size (as a control variable), and CEO duality (as a control variable) (Chams \& García-Blandón, 2019; Naciti, 2019; Yekini, Adelopo, Andrikopoulos, \& Yekini, 2015). Fourth, ownership structure was proxied by free float percentage (i.e. the rate of shares not owned by controlling shareholders and freely traded by investors) (Black, De Carvalho, \& Gorga, 2010; Kuzey \& Uyar, 2017). Fifth, financial variables, such as firm size, leverage, and profitability, were incorporated as control variables (Kang et al., 2010; Rhou et al., 2016; Youn, Hua, \& Lee, 2015). These financial variables were included as control variables for measuring CSRP for the following reasons: larger firms endure more public scrutiny in terms of environmental and social sensitivity; highly leveraged firms alleviate the sustainability concerns of credit providers and reduce borrowing costs through CSR engagement; and profitable firms have higher financial

\footnotetext{
${ }^{6}$ The country distribution of the firms included in the sample is available from the authors. Due to space constraints, we did not include this in the paper.
} 
capacity to make costly CSR investments (Kuzey \& Uyar, 2017). These variables were included as control variables for measuring firms' financial performance for the following reasons: firm size may impact firms' financial performance through economies of scale (Lee, 2009); and leverage influences firms' financial performance due to its disciplining role (González, 2013) and the provision of capital for investment (Vithessonthi \& Tongurai, 2015). The definitions of the variables used in this study are provided in Table A in the Appendix.

\subsection{Descriptive Statistics}

Table 1 shows a summary of the sample with the included variables. The descriptive statistics concerning CSRP indicated that the mean ESGscore is $49.66 \% \pm 17.23 \%$, the ENVpilscore is $50.71 \% \pm 21.08 \%$, the SOCpilscore is $51.55 \% \pm 21.72 \%$, and the GOVpilscore is $46.29 \% \pm$ $19.73 \%$. Additionally, the BC showed that the mean Bindepend is $73.55 \% \pm 16.18 \%$, Bdiversity is $16.10 \% \pm 12.32 \%$, and Bdiligence is $87 \% \pm 10.44 \%$. The mean values of the financial variables indicated that leverage is $60.93 \% \pm 27.62 \%$, profitability is $6.86 \% \pm 7.12 \%$, and Tobin Q is 1.87 \pm 1.50 . The firm-year records indicated that $46.20 \%$ of the firms have CSR committees and $45 \%$ demonstrate the existence of CEOduality.

\section{INSERT TABLE 1 HERE}

\subsection{Correlation Analysis}

Table 2 presents the bivariate linear relationship with respect to Pearson's correlation analysis. According to the analysis results, ESGscore, ENVpilscore, SOCpilscore, and GOVpilscore have significant positive linear relationships with CSRcommittee, Bindepend, Bdiversity, and Bdiligence $(\mathrm{p}<0.05)$. In addition, Tobin $\mathrm{Q}$ has no significant linear association with ESGscore, ENVpilscore, and GOVpilscore ( $\mathrm{p}>0.05$ ), but a significant negative linear association with SOCpilscore $(\mathrm{p}<0.05)$. Profitability has no significant linear relationship with ESGscore, SOCpilscore, and GOVpilscore ( $\mathrm{p}>0.05$ ), but a significant negative linear relationship with ENVpilscore $(\mathrm{p}<0.05)$.

\section{INSERT TABLE 2 HERE}

\subsection{Empirical Methodology}

This study uses two models: Model 1 is to test the association between BC and CSRP, and Model 2 is to examine the association between CSRP and financial performance. Both models 
were subjected to panel data regression analysis with fixed effects estimators. The research data are based on firm-year panel data. The records include repeated observations for the same variables for eight years between 2011 and 2018. Due to the data structure, we used panel data regression analysis with fixed effects estimators as the primary research analysis tool to test the proposed hypotheses. The two models are formulated based on the hypotheses as:

$y_{i t}=\alpha+x_{i t} \beta+v_{i}+\epsilon_{i t}$

In Model 1, " $y_{i t}$ " shows CSRP, " $x_{i t}$ " shows the BC and control variables, " $v_{i}+\epsilon_{i t}$ " is the error term, the index " $i$ " represents firm and the index " $t$ " represents year. CSRP is proxied by ESGscore, ENVpilscore, SOCpilscore, and GOVpilscore, while BC is proxied by CSRcommittee, Bindepend, Bdiversity, and Bdiligence. Similarly, in Model 2 " $y_{i t}$ " represents firm performance and " $x_{i t}$ " represents CSRP and the control variables, while firm performance is proxied by two indicators: Tobin Q and profitability (ROA).

To decide between using a random effects estimator and a fixed effects estimator, we employed Hausman's specification test (Hausman, 1978). The Hausman's test results showed that the null hypothesis (H0: Difference in coefficients not systematic_random effects) is rejected (pvalues < 0.05) in Model 1 and Model 2. Thus, the individual-level effects sufficiently modeled by a random effects estimator are rejected in favor of a fixed effects estimator.

\section{Findings and Discussion}

The results of Model 1 with fixed effects estimators are shown in Table 3. Accordingly, CSRcommittee $(\mathrm{p}<0.01)$, Bindepend $(\mathrm{p}<0.01)$, Bdiversity $(\mathrm{p}<0.01)$, and Bdiligence $(\mathrm{p}<0.05)$ have a significant positive relationship with ESGscore (Column 1) and GOVpilscore (Column 4). In addition, CSRcommittee $(\mathrm{p}<0.01)$ and Bdiversity $(\mathrm{p}<0.01)$ have a significant positive association with ENVpilscore, but Bindepend and Bdiligence have no significant association with ENVpilscore (Column 2). Finally, CSRcommittee ( $p<0.01)$, Bdiversity ( $p<0.01)$, and Bdiligence $(\mathrm{p}<0.05)$ have a significant positive relationship with SOCpilscore, but Bindepend has no significant relationship with SOCpilscore (Column 3). These results confirm the validity of H1 and H4 and all their sub-hypotheses, and support the main hypotheses of H2 (a, c, d) and H3 (a, d) with some of their sub-hypotheses. The results are discussed in line with prior studies in the following paragraphs, but theoretical and practical implications are suggested in the last section of the study. 
The evidence concerning the association between board gender diversity and CSRP or reporting is mixed in the literature depending on the context. While some studies conducted in developed countries found a positive relationship between the proportion of females on boards and CSRP (García Martín \& Herrero, 2020; Mallin \& Michelon, 2011), other studies implemented in emerging countries found a negative relationship (Gallego-Álvarez \& Pucheta-Martínez, 2020; Muttakin, Khan, \& Subramaniam, 2015). The contrasting evidence might arise from the empowerment or skills of female directors in these two types of countries. Although these studies shed light on the role of female directors in CSR practices, they were not conducted for the H\&T industry; accordingly, they do not provide sectoral implications. The findings of our study show that female directors are influential in all dimensions of CSRP, implying that they are an important mechanism of firm governance in pursuing CSR goals in the H\&T industry.

Few studies have investigated the link between board diligence and the CSRP or disclosure of firms (García Martín \& Herrero, 2020; Giannarakis, 2014; Hussain et al., 2018). The cited studies mostly used the number of meetings rather than directors' board meeting attendance rate, as in our study. The number of board meetings alone does not play a precise role in the efficiency of board meetings; García Martín and Herrero (2020) and Hussain et al. (2018) propose two contrasting views that more frequent meetings may indicate efficiency as well as inefficiency of board meetings. Their findings appear to be in line with other contradicting perspectives: Hussain et al. (2018) found a positive association between board meeting frequency and environmental performance, but not social performance; García Martín and Herrero (2020) found a positive association between board meeting frequency and environmental performance ${ }^{7}$; and Giannarakis (2014) found that board meeting frequency had a neutral effect on CSRP. However, our study uses a better proxy for board diligence: directors' board meeting attendance rate (Lin et al., 2014). Unlike the number of meetings, directors' participation reflects the efficiency of corporate board meetings. In line with the theoretical proposition, we found that the higher the directors' meeting attendance rate, the higher the composite CSRP as well as social and governance performance. This finding justifies that board diligence enhances the monitoring effectiveness of directors on boards (Yekini et al., 2015).

\footnotetext{
${ }^{7}$ This study used only the environmental dimension of CSRP.
} 
Independent board members are tough monitors and aim to align the interest of managers with those of shareholders (Adams \& Ferreira, 2007). With the growing importance of CSR, recent studies proposed that independent directors may also align the interests of firms with those of stakeholders (Gallego-Álvarez \& Pucheta-Martínez, 2020), and tested this proposition by incorporating board independence in CSR studies. However, the findings are inconclusive; some studies found that board independence improves CSR engagement (Arayssi et al., 2019; GallegoÁlvarez \& Pucheta-Martínez, 2020), others found that it decreases (Adel, Hussain, Mohamed, \& Basuony, 2019), and still others found a neutral effect (Michelon \& Parbonetti, 2012). Therefore, our study provides additional evidence of the influence of independent directors on CSRP. The findings show independent directors' limited interference in CSR issues; while they are influential in the governance dimension of CSR, they are not at all influential in the environmental and social dimensions.

Moreover, the findings of prior studies regarding the association between CSR committees and CSRP or reporting largely proved the existence of a positive relationship between the two variables, regardless of context, although there are some exceptions. While some European studies found a positive association between CSR committee and CSRP (Adel et al., 2019; García Martín \& Herrero, 2020), another study sampling European and US firms found only a weak association between CSR committee and the social dimension of CSR disclosure, but not other dimensions; the authors attribute this situation to the immaturity or small proportion of CSR committees in the sampled firms (Michelon \& Parbonetti, 2012). Past evidence also indicated that CSR committees are influential in fostering CSR practices of firms in emerging countries (Arayssi et al., 2019; Gallego-Álvarez \& Pucheta-Martínez, 2020). As sectoral evidence, Uyar et al. (2020) proved that logistics firms with CSR committees are more likely to publish a higher number of CSR reports over the years. Therefore, the finding of this study is in line with those of most prior studies and demonstrates that CSR committees are influential particularly in the H\&T industry's CSR commitment. H\&T firms with CSR committees are more likely to achieve higher composite CSRP as well as greater environmental, social, and governance performance.

\section{INSERT TABLE 3 HERE}

Moreover, in Model 2, we tested whether firm financial performance proxied by Tobin Q (i.e. market-based performance) and ROA (i.e. accounting-based performance) is associated with 
CSRP. Table 4 provides the panel data regression with fixed effects analysis results for this investigation. The testing CSRP variables proxied by ESGscore, ENVpilscore, SOCpilscore, and GOVpilscor are not simultaneously subjected to the panel regression analysis due to their high correlation (see the correlation analysis results in Table 2). Therefore, the risk of multicollinearity is eliminated.

Initially, the results showed that ESGscore, ENVpilscore, SOCpilscore, and GOVpilscore have no significant association with Tobin $\mathrm{Q}$ in (p-values > 0.05, Columns 1-4). Additionally, the results of the relationship between CSRP and profitability (ROA) as another indicator of firm performance revealed that ESGscore (p-value < 0.10) and GOVpilscore (p-value < 0.10) have weak significant negative relationships with ROA, SOCpilscore (p-value < 0.05) has a significant negative relationship with ROA, and ENVpilscore has no significant relationship with ROA (Columns 5-8). Thus, H5 is not supported, revealing that CSRP does not necessarily lead to positive financial performance in the H\&T industry.

\section{INSERT TABLE 4 HERE}

The association between CSRP and financial performance is argued on two contrasting grounds: one approach is that CSR causes firms to incur additional costs and thus reduces firms' financial performance; another is that CSR promises competitive advantage in the marketplace and thus increases firms' performance (Lee, Seo, \& Sharma, 2013). In line with these two conflicting views, the findings of prior studies are inconclusive. While Inoue and Lee (2011) found an insignificant association between CSRP and financial performance in most of the study models, they determined rarely positive and negative associations depending on the tourism subsector chosen, dependent variable specification (ROA or Tobin Q) or chosen sub-CSR dimension. Youn et al. (2015) proved a positive link for larger firms rather than the overall sample in the restaurant industry. Drawing on a synthesis of a comprehensive literature review, Coles, Fenclova, and Dinan (2013) concluded that the findings on the CSRP and firm performance nexus are unequivocal. In line with these prior studies, our results also did not produce consistent outcomes; while the fixed effects estimator did not yield any significant result for Tobin Q, composite CSRP as well as social and governance indicators produced significant negative results for ROA, confirming the approach that CSR causes additional costs.

\subsection{Robustness Checks}


Model 1 and Model 2 were subjected to robustness checks using ordinary least square (OLS) regression analysis. Table 5 presents Model 1's analysis results. The results confirmed all the significant relationships except one (between Bindepend and GOVpilscore) found in Table 3. Moreover, the insignificant associations between Bindepend and ENVpilscore, Bindepend and SOCpilscore, and Bdiligence and ENVpilscore obtained in Table 3 were all found significant (p < 0.01) in robustness tests. We conclude that the findings regarding the BC driving CSRP are robust compared to alternative methodologies.

\section{INSERT TABLE 5 HERE}

Similarly, Model 2 was also subjected to robustness checks using OLS. The results are given in Table 6. Based on the obtained results, none of the CSRP indicators has a significant association with Tobin Q, which indicates consistency with the initial analysis. Only ESGscore (p-value < 0.05 ) and GOVpilscore (p-value < 0.01) have a significant positive association with profitability, contrary to the negative associations obtained in Table 4. Hence, it can be said that the association between CSRP and ROA varies depending on the methodology chosen.

\section{INSERT TABLE 6 HERE}

\section{Conclusions}

In this study, we tested and explored whether the characteristics of corporate boards are likely to affect the CSRP of H\&T companies, and whether CSRP plays a role in enhancing firms' performance. We hope that our study will help sector representatives design corporate structures that enhance their CSRP. Our study draws significant conclusions that are robust compared to alternative methodologies and are based on a cross-country sample.

The results suggest that CSR committees make a significant difference in driving firms' CSR engagements. This result is confirmed for the composite ESG score and individual ESG pillars, including environmental, social, and governance. This implies that CSR committees are influential in pursuing CSR goals and addressing stakeholders' demands in all dimensions. Our findings validate the necessity of board sub-committees, in which specific tasks are assigned to fewer decision-makers. Second, an independent board of directors is particularly effective in improving firms' overall CSR commitments and the governance pillar. This might mean that independent directors are appointed to boards to strengthen the governance structure, through which long-term 
value generation is enabled and shareholders' interests are met. Third, the ratio of female directors on boards is highly influential in driving firms to engage with all CSR dimensions. The findings and propositions of prior studies assert that women are more philanthropically driven and community-oriented, have diverse perspectives, and bring unique experiences and competencies to boards. Fourth, disciplined directors also contribute to the composite score and the social and governance pillars of CSR engagement. By participating in board meetings, directors have a chance to be knowledgeable about CSR investments, vote for investing in specific CSR projects, and follow up on the outcomes of those projects, since those meetings are the primary decisionmaking platform for such investments. Finally, CSRP does not enhance firms' performance as proxied by both value-based and accounting-based indicators.

\section{Theoretical and Practical Implications}

The findings imply that the resource dependence and upper echelons theories explain the CSRP of H\&T firms well. In line with the resource dependence theory, female directors and CSR committees might enrich H\&T firms' CSR agenda, engagement with their experience, expertise, knowledge, and skills, and communication of CSRP with external parties. In line with the upper echelons theory, the study proves the influence of upper level corporate structure and meetings on corporate decision-making and shaping firms' CSR practices. The only weak link between board structure and CSRP is the effect of independent directors on CSRP. For each of the hypothesized links, the study provides practical implications in the following paragraphs.

The findings propose a straightforward roadmap for H\&T firms and policymakers to follow to identify the characteristics of CSR-friendly boards that pursue, monitor, and prioritize the CSR commitment of firms. First, as CSR committees and gender diverse boards improve all types of CSR engagements, H\&T sector representatives may formulate or redesign corporate policies to establish specific CSR committees and open seats to female directors on the boards. The findings highlight the importance of board structure in pursuing CSR goals as the ultimate decision-making body in corporations. It is hoped that CSR policies shaped at board level might have a domino effect on the lower hierarchical levels of management and human resource structure, ultimately aligning H\&T firms with more environmentally and socially responsible practices. Already existing rates of CSR committees (46.2\%) and board diversity (16.1\%) can be raised. However, the scarcity of women in the sector might be a symptom of gender inequality in the H\&T academia 
since Khoo-Lattimore, Yang, and Je (2019) point out underrepresentation of women in tourismrelated academic conferences and calling for more women participation in the events. In 2010, the United Nations World Tourism Organization (UNWTO) also released a report highlighting the gender gap in international tourism (Khoo-Lattimore, Yang, \& Je, 2019). At this point, H\&T schools may undertake an important role to educate future women leaders and practitioners by countering gender discrimination (if exists), updating curricula, teaching soft skills along with hard skills which eventually may serve to empower women in the sector (Mooney, 2020). Second, as board diligence is a significant predictor of composite CSRP as well as social and governance pillar performance, it implies that social and managerial issues of H\&T firms are the subjects of board meetings. However, as board diligence is not a significant predictor of the environmental pillar, it might signal that environmental issues are not prioritized on the corporate agenda as much as other CSR issues. Hence, the environmental dimension of CSR requires closer attention in board meetings and from directors of H\&T firms due to the sector's negative influence on the environment (e.g. carbon emissions from air transportation and accommodation), as well as its economic self-interest in protecting the environment.

Third, despite the high rate of independent directors on boards (73.55\%), they have limited influence on the CSR commitment of H\&T firms; they have an effect on the composite CSR score as well as the governance pillar. This finding casts doubt on the efficacy or responsibility of independent directors regarding environmental and social issues. This situation can be explained by the fact that they might focus on financial issues and oversight of managers to secure the interests of shareholders. They may consider environmental and social initiatives as nonessential and regard them as activities that distract them from their primary goal of pursuing shareholders' interests. Moreover, independent directors might leave environmental and social issues to the discretion of CSR committees and female directors.

Fourth, the findings may help policymakers advance CSR implementation in the H\&T sector. As the study connects board configuration to CSRP, policies can be developed for better configuration of boards and improvement of CSRP. For policymakers, one way is to formulate corporate governance codes to address board structure, such as fixing the rates of female and nonexecutive directors on boards, requiring firms to establish CSR committees, and setting a meeting attendance rate for directors. Another way is to take or suggest concrete steps to alleviate the environmental degradation caused by the H\&T sector and enhance social engagement, such as 
community development. This can be done through governmental and non-governmental tourism offices or other local bodies concerned with tourism activities.

Finally, the insignificant association between CSRP and firms' financial performance implies that CSR initiatives may not yield financial returns in the short term. Firms may have to wait a long time to realize the financial benefits of such initiatives. Another plausible explanation is that the H\&T sector may expect non-financial benefits (i.e. achieving social legitimacy or community development) rather than financial gains from CSR activities. Alternatively, the stock market may not be efficient enough, as it does not reflect CSR information in share values, which may indicate that firms are not sufficiently communicating their CSR activities with their shareholders ${ }^{8}$. At this point, we think that female directors might play a significant role in turning CSR efforts to firm performance as there are some studies which found a positive association between board diversity and firm performance (Campbell \& Mínguez-Vera, 2008; Reguera-Alvarado, de Fuentes, \& Laffarga, 2017). They can do that by building relations with the external environment and stakeholders (Mallin \& Michelon, 2011) through traditional and conventional communication technologies. Hence, corporations might develop new strategies for marketing and investor relations for better benefiting from female directors in improving not solely CSR performance but also financial performance. However, to do that, the existing female proportion on boards $(16.1 \%)$ may not be sufficient suggesting the need for opening more room to females on boardrooms. Some studies even suggest regulatory intervention by governmental authorities to raise women proportion on boards through corporate governance codes (Reguera-Alvarado et al., 2017) as some European countries do (Jiraporn, Bouattour, Hamrouni, \& Uyar, 2019). Moreover, the insignificant association between CSRP and profitability might signal that CSR initiatives are costly investments that do not allow for improved net income on the income statement. If this is the case, H\&T firms should try to translate CSR initiatives into higher levels of sales revenue to ultimately improve profitability. They can do this by developing better customer and public relations with the help of their marketing and customer relations units.

The findings should be considered in light of two main limitations. The sample comprises H\&T firms for the years between 2011 and 2018. Therefore, the results may not be generalizable for other sectors or may not be valid before the year 2011. The validity of the results could be

\footnotetext{
${ }^{8}$ This comment is relevant particularly for a market-based performance indicator (i.e. Tobin Q).
} 
checked in other environmentally sensitive industries, such as energy, logistics, aviation, chemicals, and mining. Future studies could consider institutional or country-level factors beyond firm-level indicators to check whether they are influential in motivating firms to perform CSR activities. Particularly for the H\&T sector, binding regulations, sanctions or civil society influence may be more powerful in some countries; this could potentially force sector representatives to undertake certain CSR exercises. Finally, the insignificant association between CSRP and financial performance justifies future investigations. Moderators such as the quality of the institutional environment or the size of the tourism sector could be incorporated in the study models.

\section{References}

Adams, R. B., \& Ferreira, D. (2007). A theory of friendly boards. The Journal of Finance, 62(1), 217-250.

Adams, R. B., \& Ferreira, D. (2009). Women in the boardroom and their impact on governance and performance. Journal of Financial Economics, 94(2), 291-309.

Adel, C., Hussain, M. M., Mohamed, E. K., \& Basuony, M. A. (2019). Is corporate governance relevant to the quality of corporate social responsibility disclosure in large European companies?. International Journal of Accounting \& Information Management, 27(2), 301332.

Amran, A., Lee, S. P., \& Devi, S. S. (2014). The influence of governance structure and strategic corporate social responsibility toward sustainability reporting quality. Business Strategy and the Environment, 23(4), 217-235.

Arayssi, M., Jizi, M., \& Tabaja, H. H. (2019). The impact of board composition on the level of ESG disclosures in GCC countries. Sustainability Accounting, Management and Policy Journal, 11(1), 137-161.

Bear, S., Rahman, N., \& Post, C. (2010). The impact of board diversity and gender composition on corporate social responsibility and firm reputation. Journal of Business Ethics, 97(2), 207-221.

Benavides-Velasco, C. A., Quintana-García, C., \& Marchante-Lara, M. (2014). Total quality management, corporate social responsibility and performance in the hotel industry. International Journal of Hospitality Management, 41, 77-87. 
Bird, R., Hall, A. D., Momentè, F., \& Reggiani, F. (2007). What corporate social responsibility activities are valued by the market?. Journal of Business Ethics, 76(2), 189-206.

Black, B. S., De Carvalho, A. G., \& Gorga, E. (2010). Corporate governance in Brazil. Emerging Markets Review, 11(1), 21-38.

Boluk, K. (2013). Using CSR as a tool for development: An investigation of the fair hotels scheme in Ireland. Journal of Quality Assurance in Hospitality \& Tourism, 14(1), 49-65.

Bose, S., Khan, H. Z., Rashid, A., \& Islam, S. (2018). What drives green banking disclosure? An institutional and corporate governance perspective. Asia Pacific Journal of Management, $35(2), 501-527$.

Buchanan, B., Cao, C. X., \& Chen, C. (2018). Corporate social responsibility, firm value, and influential institutional ownership. Journal of Corporate Finance, 52, 73-95.

Burke, J. J., Hoitash, R., \& Hoitash, U. (2019). The heterogeneity of board-level sustainability committees and corporate social performance. Journal of Business Ethics, 154(4), 11611186.

Campbell, K., \& Mínguez-Vera, A. (2008). Gender diversity in the boardroom and firm financial performance. Journal of Business Ethics, 83(3), 435-451.

Chams, N., \& García-Blandón, J. (2019). Sustainable or not sustainable? The role of the board of directors. Journal of Cleaner Production, 226, 1067-1081.

Chen, L., Feldmann, A., \& Tang, O. (2015). The relationship between disclosures of corporate social performance and financial performance: Evidences from GRI reports in manufacturing industry. International Journal of Production Economics, 170, 445-456.

Chou, H. I., Chung, H., \& Yin, X. (2013). Attendance of board meetings and company performance: Evidence from Taiwan. Journal of Banking \& Finance, 37(11), 4157-4171.

Coles, T., Fenclova, E., \& Dinan, C. (2013). Tourism and corporate social responsibility: A critical review and research agenda. Tourism Management Perspectives, 6, 122-141.

Cullinan, C. P., Mahoney, L. S., \& Roush, P. B. (2018). External CSR rating influence on shareholder voting patterns for CSR shareholder-sponsored proposals. Research on Professional Responsibility and Ethics in Accounting, 21, 83-110. 
De Beelde, I., \& Tuybens, S. (2015). Enhancing the credibility of reporting on corporate social responsibility in Europe. Business Strategy and the Environment, 24(3), 190-216.

de Grosbois, D. (2012). Corporate social responsibility reporting by the global hotel industry: Commitment, initiatives and performance. International Journal of Hospitality Management, 31(3), 896-905.

Dell'Atti, S., Trotta, A., Iannuzzi, A. P., \& Demaria, F. (2017). Corporate social responsibility engagement as a determinant of bank reputation: An empirical analysis. Corporate Social Responsibility and Environmental Management, 24(6), 589-605.

Eliwa, Y., Aboud, A., \& Saleh, A. (2019). ESG practices and the cost of debt: Evidence from EU countries. Critical Perspectives on Accounting, in press.

Eluyela, D. F., Akintimehin, O. O., Okere, W., Ozordi, E., Osuma, G. O., Ilogho, S. O., \& Oladipo, O. A. (2018). Board meeting frequency and firm performance: Examining the nexus in Nigerian deposit money banks. Heliyon, 4(10), e00850.

Fernandes, N. (2008). EC: Board compensation and firm performance: The role of "independent" board members. Journal of Multinational Financial Management, 18(1), 30-44.

Font, X., \& Lynes, J. (2018). Corporate social responsibility in tourism and hospitality. Journal of Sustainable Tourism, 26(7), 1027-1042.

Franco, S., Caroli, M. G., Cappa, F., \& Del Chiappa, G. (2019). Are you good enough? CSR, quality management and corporate financial performance in the hospitality industry. International Journal of Hospitality Management, 102395.

Gafoor, C. A., Mariappan, V., \& Thyagarajan, S. (2018). Board characteristics and bank performance in India. IIMB Management Review, 30(2), 160-167.

Gallego - Álvarez, I., \& Pucheta - Martínez, M. C. (2020). Corporate social responsibility reporting and corporate governance mechanisms: An international outlook from emerging countries. Business Strategy \& Development, 3(1), 77-97.

García Martín, C. J., \& Herrero, B. (2020). Do board characteristics affect environmental performance? A study of EU firms. Corporate Social Responsibility and Environmental Management, 27(1), 74-94. 
Garcia, A. S., Mendes-Da-Silva, W., \& Orsato, R. J. (2017). Sensitive industries produce better ESG performance: Evidence from emerging markets. Journal of Cleaner Production, 150, 135-147.

García-Sánchez, I. M., Hussain, N., \& Martínez-Ferrero, J. (2019). An empirical analysis of the complementarities and substitutions between effects of CEO ability and corporate governance on socially responsible performance. Journal of Cleaner Production, 215, 1288-1300.

Ghaderi, Z., Mirzapour, M., Henderson, J. C., \& Richardson, S. (2019). Corporate social responsibility and hotel performance: A view from Tehran, Iran. Tourism Management Perspectives, 29, 41-47.

Giannarakis, G. (2014). Corporate governance and financial characteristic effects on the extent of corporate social responsibility disclosure. Social Responsibility Journal, 10(4), 569-590.

Godos-Díez, J. L., Cabeza-García, L., Alonso-Martínez, D., \& Fernández-Gago, R. (2018). Factors influencing board of directors' decision-making process as determinants of CSR engagement. Review of Managerial Science, 12(1), 229-253.

González, V. M. (2013). Leverage and corporate performance: International evidence. International Review of Economics \& Finance, 25, 169-184.

González-Rodríguez, M. R., Martín-Samper, R. C., Köseoglu, M. A., \& Okumus, F. (2019). Hotels' corporate social responsibility practices, organizational culture, firm reputation, and performance. Journal of Sustainable Tourism, 27(3), 398-419.

Guillet, B. D., \& Mattila, A. S. (2010). A descriptive examination of corporate governance in the hospitality industry. International Journal of Hospitality Management, 29(4), 677-684.

Gürlek, M., \& Tuna, M. (2019). Corporate social responsibility and work engagement: Evidence from the hotel industry. Tourism Management Perspectives, 31, 195-208.

Gürlek, M., Düzgün, E., \& Meydan Uygur, S. (2017). How does corporate social responsibility create customer loyalty? The role of corporate image. Social Responsibility Journal, 13(3), 409-427. 
Hambrick, D. C. (2007). Upper echelons theory: An update. Academy of Management Review, 32(2), 334-343.

Hambrick, D. C., \& Mason, P. A. (1984). Upper echelons: The organization as a reflection of its top managers. Academy of Management Review, 9(2), 193-206.

Hausman, J. A. (1978). Specification tests in econometrics. Econometrica, 46, 1251-1271.

He, J., Zhang, H., \& Morrison, A. M. (2019). The impacts of corporate social responsibility on organization citizenship behavior and task performance in hospitality: A sequential mediation model. International Journal of Contemporary Hospitality Management, 31(6), 2582-2598.

Helfaya, A., \& Moussa, T. (2017). Do board's corporate social responsibility strategy and orientation influence environmental sustainability disclosure? UK evidence. Business Strategy and the Environment, 26(8), 1061-1077.

Hillman, A. J., \& Dalziel, T. (2003). Boards of directors and firm performance: Integrating agency and resource dependence perspectives. The Academy of Management Review, 28(3), 383396.

Hillman, A. J., Shropshire, C., \& Cannella, A. A. (2007). Organizational predictors of women on corporate boards. Academy of Management Journal, 50(4), 941-952.

Hoitash, U. (2011). Should independent board members with social ties to management disqualify themselves from serving on the board?. Journal of Business Ethics, 99(3), 399-423.

Hussain, N., Rigoni, U., \& Orij, R.P. (2018). Corporate governance and sustainability performance: Analysis of triple bottom line performance. Journal of Business Ethics, 149(2), 411-432.

Inoue, Y., \& Lee, S. (2011). Effects of different dimensions of corporate social responsibility on corporate financial performance in tourism-related industries. Tourism Management, 32(4), 790-804.

Iyer, G. R., \& Jarvis, L. (2019). CSR adoption in the multinational hospitality context: A review of representative research and avenues for future research. International Journal of Contemporary Hospitality Management. 31(6), 2376-2393. 
Jamali, D., \& Karam, C. (2018). Corporate social responsibility in developing countries as an emerging field of study. International Journal of Management Reviews, 20(1), 32-61.

Jiraporn, P., Bouattour, M., Hamrouni, A., \& Uyar, A. (2019). Does board gender diversity influence dividend policy? Evidence from France. Economics Bulletin, 39(4), 2942-2954.

Kang, K. H., Lee, S., \& Huh, C. (2010). Impacts of positive and negative corporate social responsibility activities on company performance in the hospitality industry. International Journal of Hospitality Management, 29(1), 72-82.

Khatter, A., McGrath, M., Pyke, J., White, L., \& Lockstone-Binney, L. (2019). Analysis of hotels' environmentally sustainable policies and practices: Sustainability and corporate social responsibility in hospitality and tourism. International Journal of Contemporary Hospitality Management, 31(6), 2394-2410.

Khoo-Lattimore, C., Yang, E. C., \& Je, J. S. (2019). Assessing gender representation in knowledge production: a critical analysis of UNWTO's planned events. Journal of Sustainable Tourism, 27(7), 920-938.

Kiliç, M., Kuzey, C., \& Uyar, A. (2015). The impact of ownership and board structure on Corporate Social Responsibility (CSR) reporting in the Turkish banking industry. Corporate Governance, 15(3), 357-374.

Kucukusta, D., Mak, A., \& Chan, X. (2013). Corporate social responsibility practices in four and five-star hotels: Perspectives from Hong Kong visitors. International Journal of Hospitality Management, 34, 19-30.

Kuzey, C., \& Uyar, A. (2017). Determinants of sustainability reporting and its impact on firm value: Evidence from the emerging market of Turkey. Journal of Cleaner Production, 143, 27-39.

Lee, C. I., Rosenstein, S., Rangan, N., \& Davidson III, W. N. (1992). Board composition and shareholder wealth: The case of management buyouts. Financial Management, 21(1), 5872.

Lee, J. (2009). Does size matter in firm performance? Evidence from US public firms. International Journal of the Economics of Business, 16(2), 189-203. 
Lee, S., Seo, K., \& Sharma, A. (2013). Corporate social responsibility and firm performance in the airline industry: The moderating role of oil prices. Tourism Management, 38, 20-30.

Liao, L., Lin, T. P., \& Zhang, Y. (2018). Corporate board and corporate social responsibility assurance: Evidence from China. Journal of Business Ethics, 150(1), 211-225.

Liao, L., Luo, L., \& Tang, Q. (2015). Gender diversity, board independence, environmental committee and greenhouse gas disclosure. The British Accounting Review, 47(4), 409-424.

Lima Crisóstomo, V., de Souza Freire, F., \& Cortes de Vasconcellos, F. (2011). Corporate social responsibility, firm value and financial performance in Brazil. Social Responsibility Journal, 7(2), 295-309.

Lin, Y. F., Yeh, Y. M. C., \& Yang, F. M. (2014). Supervisory quality of board and firm performance: A perspective of board meeting attendance. Total Quality Management \& Business Excellence, 25(3-4), 264-279.

Lipton, M. \& Lorsch, J. W. (1992). A modest proposal for improved corporate governance. The Business Lawyer, 48, 59-17.

Luo, X., Wang, H., Raithel, S., \& Zheng, Q. (2015). Corporate social performance, analyst stock recommendations, and firm future returns. Strategic Management Journal, 36(1), 123-136.

Mahmood, M., \& Orazalin, N. (2017). Green governance and sustainability reporting in Kazakhstan's oil, gas, and mining sector: Evidence from a former USSR emerging economy. Journal of Cleaner Production, 164, 389-397.

Mallin, C. A., \& Michelon, G. (2011). Board reputation attributes and corporate social performance: An empirical investigation of the US best corporate citizens. Accounting and Business Research, 41(2), 119-144.

McGuinness, P. B., Vieito, J. P., \& Wang, M. (2017). The role of board gender and foreign ownership in the CSR performance of Chinese listed firms. Journal of Corporate Finance, 42, 75-99.

McWilliams, A., \& Siegel, D. (2000). Corporate social responsibility and financial performance: Correlation or misspecification?. Strategic Management Journal, 21(5), 603-609. 
Michelon, G., \& Parbonetti, A. (2012). The effect of corporate governance on sustainability disclosure. Journal of Management \& Governance, 16(3), 477-509.

Mihalic, T. (2016) Sustainable-responsible tourism discourse-towards 'responsustable' tourism. Journal of Cleaner Production, 111, 461-470.

Mishra, S., \& Mohanty, P. (2014). Corporate governance as a value driver for firm performance: Evidence from India. Corporate Governance, 14(2), 265-280.

Moneva, J. M., Bonilla-Priego, M. J., \& Ortas, E. (2019). Corporate social responsibility and organisational performance in the tourism sector. Journal of Sustainable Tourism, 28(6), 853-872.

Mooney, S. K. (2020). Gender research in hospitality and tourism management: time to change the guard. International Journal of Contemporary Hospitality Management, 32(5), 18611879.

Moyeen, A., Kamal, S., \& Yousuf, M. (2019). A content analysis of CSR research in hotel industry, 2006-2017. Responsibility and governance (pp. 163-179). Singapore: Springer.

Mu Yeh, C. (2013). Board governance and tourism firms' performance: The case of Taiwan. Journal of Quality Assurance in Hospitality \& Tourism, 14(2), 123-141.

Mu Yeh, C. (2018). Does board governance matter for foreign institutional investors to invest in listed tourism firms?. Tourism Management, 68, 66-78.

$\mathrm{Mu}$ Yeh, C. (2019). Ownership structure and firm performance of listed tourism firms. International Journal of Tourism Research, 21(2), 165-179.

Muttakin, M. B., Khan, A., \& Subramaniam, N. (2015). Firm characteristics, board diversity and corporate social responsibility. Pacific Accounting Review, 27(3), 353-372.

Naciti, V. (2019). Corporate governance and board of directors: The effect of a board composition on firm sustainability performance. Journal of Cleaner Production, 237, 117727.

Okumus, F., Altinay, L., \& Chathoth, P. K., 2010. Strategic Management for Hospitality and Tourism. Elsevier, Oxford. 
Orazalin, N., \& Baydauletov, M. (2020). Corporate social responsibility strategy and corporate environmental and social performance: The moderating role of board gender diversity. Corporate Social Responsibility and Environmental Management. doi:10.1002/csr.1915

Orlitzky, M., Schmidt, F. L., \& Rynes, S. L. (2003). Corporate social and financial performance: A meta-analysis. Organization Studies, 24(3), 403-441.

Pfeffer, J., \& Salancik, G. 1978. The external control of organizations: A resource dependence perspective. New York: Harper \& Row.

Post, C., Rahman, N., \& McQuillen, C. (2015). From board composition to corporate environmental performance through sustainability-themed alliances. Journal of Business Ethics, 130(2), 423-435.

Post, C., Rahman, N., \& Rubow, E. (2011). Green governance: Boards of directors' composition and environmental corporate social responsibility. Business \& Society, 50(1), 189-223.

Pucheta-Martínez, M. C., \& Gallego-Álvarez, I. (2019). An international approach of the relationship between board attributes and the disclosure of corporate social responsibility issues. Corporate Social Responsibility and Environmental Management, 26(3), 612-627.

Qu, R. (2014). Market orientation and organizational performance linkage in Chinese hotels: The mediating roles of corporate social responsibility and customer satisfaction. Asia Pacific Journal of Tourism Research, 19, 1399-1416.

Refinitiv (2019a). Eikon, retrieved from https://www.refinitiv.com/en/products/eikon-tradingsoftware (accessed 20 March 2020).

Refinitiv (2019b). Thomson Reuters Business Classification, retrieved from https://www.refinitiv.com/content/dam/marketing/en_us/documents/quick-referenceguides/trbc-business-classification-quick-guide.pdf (accessed 20 March 2020).

Refinitiv (2020). Environmental, Social and Governance (ESG) Scores from Refinitiv, retrieved from

https://www.refinitiv.com/content/dam/marketing/en_us/documents/methodology/esgscores-methodology.pdf (accessed 23 April 2020). 
Reguera-Alvarado, N., de Fuentes, P., \& Laffarga, J. (2017). Does board gender diversity influence financial performance? Evidence from Spain. Journal of Business Ethics, 141(2), 337-350.

Rhou, Y., \& Singal, M. (2020). A review of the business case for CSR in the hospitality industry. International Journal of Hospitality Management, 84, 102330.

Rhou, Y., Singal, M., \& Koh, Y. (2016). CSR and financial performance: The role of CSR awareness in the restaurant industry. International Journal of Hospitality Management, 57, 30-39.

Rodriguez-Fernandez, M. (2016). Social responsibility and financial performance: The role of good corporate governance. BRQ Business Research Quarterly, 19(2), 137-151.

Saeidi, S. P., Sofian, S., Saeidi, P., Saeidi, S. P., \& Saaeidi, S. A. (2015). How does corporate social responsibility contribute to firm financial performance? The mediating role of competitive advantage, reputation, and customer satisfaction. Journal of Business Research, 68(2), 341-350.

Scott, D., Peeters, P, \& Gossling, S. (2010) Can tourism deliver its "aspirational" greenhouse gas emission reduction targets?. Journal of Sustainable Tourism, 18(3), 393-408.

Shahab, Y., Ntim, C. G., Chengang, Y., Ullah, F., \& Fosu, S. (2018). Environmental policy, environmental performance, and financial distress in China: Do top management team characteristics matter?. Business Strategy and the Environment, 27(8), 1635-1652.

Singal, M. (2014). Corporate social responsibility in the hospitality and tourism industry: Do family control and financial condition matter? International Journal of Hospitality Management, 36, 81-89.

Singal, M. (2015). How is the hospitality and tourism industry different? An empirical test of some structural characteristics. International Journal of Hospitality Management, 47, 116-119.

Suárez-Cebador, M., Rubio-Romero, J. C., Pinto-Contreiras, J., \& Gemar, G. (2018). A model to measure sustainable development in the hotel industry: A comparative study. Corporate Social Responsibility and Environmental Management, 25(5), 722-732. 
Theodoulidis, B., Diaz, D., Crotto, F., \& Rancati, E. (2017). Exploring corporate social responsibility and financial performance through stakeholder theory in the tourism industries. Tourism Management, 62, 173-188.

Tsai, W.-H., Hsu, J.-L., Chen, C.-H., Lin, W.-R., \& Chen, S.-P. (2010). An integrated approach for selecting corporate social responsibility programs and costs evaluation in the international tourist hotel. International Journal of Hospitality Management, 29(3), 385396.

UNWTO, 2016. Tourism Highlights, 2016 edition. http://www.e unwto.org/doi/pdf/ 10.18111/9789284418145 (Retrieved 18.10.2016).

Uyar, A., Karaman, A. S., \& Kilic, M. (2020). Is corporate social responsibility reporting a tool of signaling or greenwashing? Evidence from the worldwide logistics sector. Journal of Cleaner Production, 119997.

Vafeas, N. (1999). Board meeting frequency and firm performance. Journal of Financial Economics, 53(1), 113-142.

Verardi, V., \& Dehon, C. (2010). Multivariate outlier detection in Stata. The Stata Journal, 10(2), 259-266.

Vithessonthi, C., \& Tongurai, J. (2015). The effect of firm size on the leverage-performance relationship during the financial crisis of 2007-2009. Journal of Multinational Financial Management, 29, 1-29.

Wang, Z., \& Sarkis, J. (2017). Corporate social responsibility governance, outcomes, and financial performance. Journal of Cleaner Production, 162, 1607-1616.

Wang, Z., Hsieh, T. S., \& Sarkis, J. (2018). CSR performance and the readability of CSR reports: Too good to be true?. Corporate Social Responsibility and Environmental Management, 25(1), 66-79.

Webb, E. (2004). An examination of socially responsible firms' board structure. Journal of Management and Governance, 8(3), 255-277. 
Yekini, K. C., Adelopo, I., Andrikopoulos, P., \& Yekini, S. (2015). Impact of board independence on the quality of community disclosures in annual reports. Accounting Forum, 39(4), 249267.

Youn, H., Hua, N., \& Lee, S. (2015). Does size matter? Corporate social responsibility and firm performance in the restaurant industry. International Journal of Hospitality Management, $51,127-134$.

Zhu, Y. (2013). The impact of top management team process on corporate social responsibility and firm performance. Frontiers of Business Research in China, 7, 268-288. 


\section{Appendix}

\section{Table A}

The list of variables, their definitions and the source*

\begin{tabular}{|c|c|}
\hline Variables & Definition \\
\hline ESGscore & Composite CSR score including environmental, social and corporate governance initiatives \\
\hline ENVpilscore & Environmental score which assesses a firm's impact on ecosystems. \\
\hline SOCpilscore & $\begin{array}{l}\text { Social score evaluates a company's engagements to address employees', customers', and } \\
\text { society' expectations. }\end{array}$ \\
\hline GOVpilscore & $\begin{array}{l}\text { Governance score measures the extent of which a firm's board members and executives } \\
\text { ensure long-term shareholder interest. }\end{array}$ \\
\hline CSRcommittee & Presence of a board-level CSR committee/team in the firm \\
\hline Bindepend & Board independence as calculated by the ratio of non-executive members on the board \\
\hline Bdiversity & Board diversity as measured by the ratio of female members on the board \\
\hline Bdiligence & Board diligence as proxied by board meeting attendance rate of directors \\
\hline Bsize & Board size as proxied by the number of directors on the board at the end of the fiscal year \\
\hline CEOduality & Specifies whether CEO chairs the board simultaneously \\
\hline Freefperc & Free float as a percentage of shares outstanding \\
\hline Firmsize & Natural logarithm of total assets of a company \\
\hline Leverage & The proportion of total liabilities to total assets \\
\hline Profitability & The ratio of net income (after taxes) to total assets \\
\hline Tobin Q & The total of market capitalization and total debt divided by total assets \\
\hline
\end{tabular}

* All data were collected from Thomson Reuters Eikon database. 


\section{Figure 1}

Hypothesized model of the study
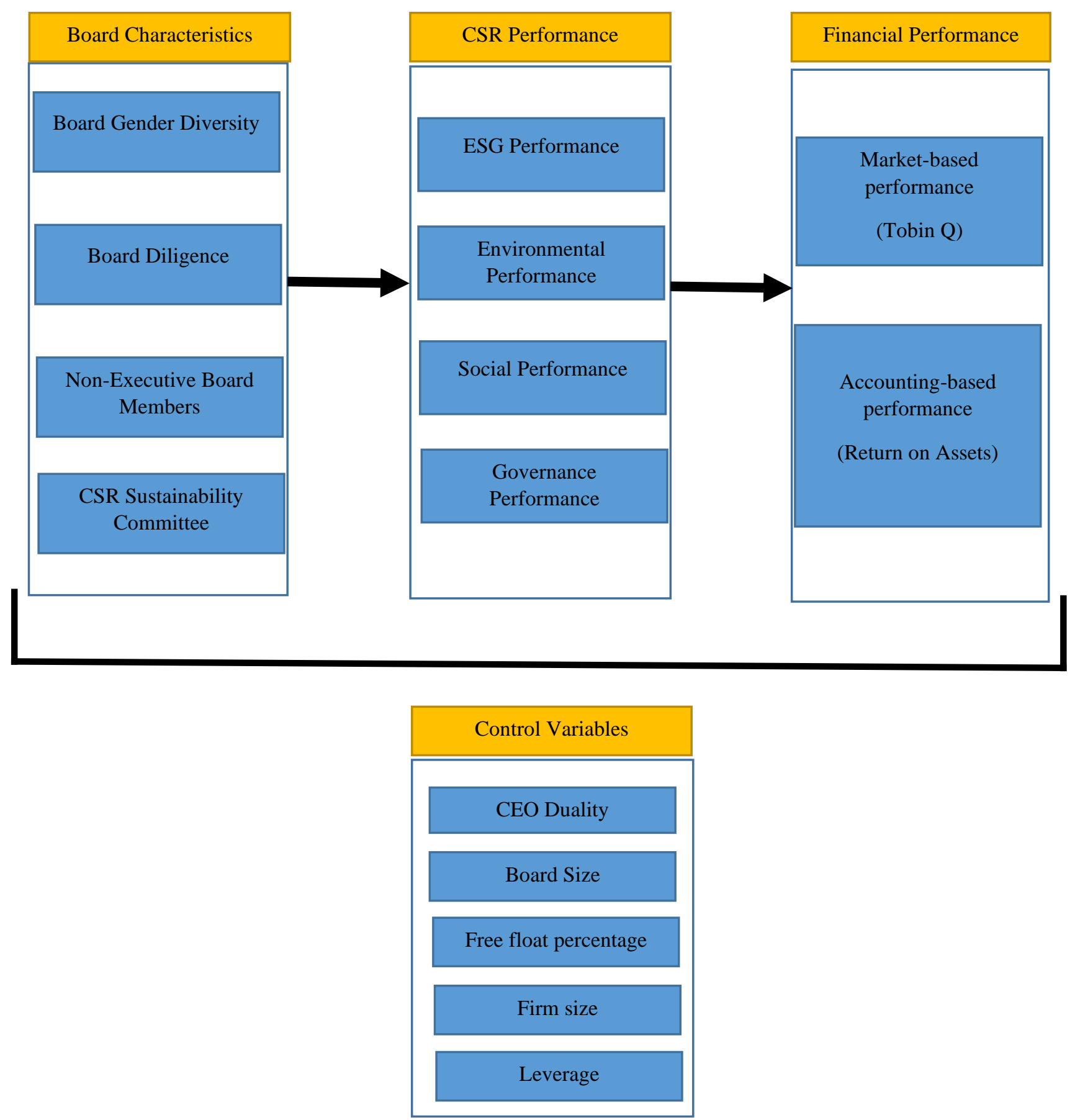
Table 1

Descriptive Statistics ( $\mathrm{N}=920)$

\begin{tabular}{|c|c|c|c|c|c|}
\hline Variables & & Mean & Std. Dev. & Min & Max \\
\hline ESGscore & & 49.66 & 17.23 & 12.65 & 92.17 \\
\hline ENVpilscore & & 50.71 & 21.08 & 15.95 & 98.68 \\
\hline SOCpilscore & & 51.55 & 21.72 & 6.53 & 98.92 \\
\hline GOVpilscore & & 46.29 & 19.73 & 5.36 & 92.28 \\
\hline Bindepend & & 73.55 & 16.18 & 0.00 & 100.00 \\
\hline Bdiversity & & 16.10 & 12.32 & 0.00 & 57.14 \\
\hline Bdiligence & & 87.00 & 10.44 & 5.00 & 100.00 \\
\hline Bsize & & 9.19 & 2.74 & 1.00 & 26.00 \\
\hline Freefperc & & 74.23 & 23.15 & 4.06 & 100.00 \\
\hline Firmsize & & 21.71 & 1.41 & 17.66 & 24.48 \\
\hline Leverage & & 60.93 & 27.62 & 5.55 & 202.97 \\
\hline Profitability & & 6.86 & 7.12 & -23.75 & 34.11 \\
\hline Tobin Q & & 1.87 & 1.50 & 0.00 & 9.39 \\
\hline \multirow{3}{*}{ CSRcommittee } & Category & & & Frequency & Percent \\
\hline & Exist & & & 425 & 46.20 \\
\hline & Does not exist & & & 495 & 53.80 \\
\hline \multirow{4}{*}{ CEOduality } & Total & & & 920 & 100.00 \\
\hline & Exist & & & 414 & 45.00 \\
\hline & Does not exist & & & 506 & 55.00 \\
\hline & Total & & & 920 & 100.00 \\
\hline
\end{tabular}


Table 2

Pearson's correlation analysis

\begin{tabular}{lllllllll}
\hline Variables & V1 & V2 & V3 & V4 & V5 & V6 & V7 & V8 \\
\hline 1: ESGscore & 1 & & & & & & & \\
2: ENVpilscore & $0.878^{*}$ & 1 & & & & & & \\
3: SOCpilscore & $0.899^{*}$ & $0.761^{*}$ & 1 & & & & & \\
4: GOVpilscore & $0.666^{*}$ & $0.346^{*}$ & $0.386^{*}$ & 1 & & & & \\
5: CSRcommittee & $0.687^{*}$ & $0.687^{*}$ & $0.623^{*}$ & $0.349^{*}$ & 1 & & & \\
6: Bindepend & $0.281^{*}$ & $0.214^{*}$ & $0.339^{*}$ & $0.116^{*}$ & $0.103^{*}$ & 1 & & \\
7: Bdiversity & $0.372^{*}$ & $0.262^{*}$ & $0.319^{*}$ & $0.345^{*}$ & $0.173^{*}$ & $0.223^{*}$ & 1 & \\
8: Bdiligence & $0.142^{*}$ & $0.120^{*}$ & $0.110^{*}$ & $0.123^{*}$ & $0.185^{*}$ & $-0.193^{*}$ & -0.024 & 1 \\
9: Bsize & $0.392^{*}$ & $0.416^{*}$ & $0.380^{*}$ & $0.140^{*}$ & $0.354^{*}$ & $0.241^{*}$ & $0.175^{*}$ & $-0.160^{*}$ \\
10: CEOduality & -0.013 & $0.078^{*}$ & $-0.07^{*}$ & -0.004 & -0.032 & $0.098^{*}$ & $-0.115^{*}$ & $-0.363^{*}$ \\
11: Freefperc & $0.162^{*}$ & $0.092^{*}$ & $0.190^{*}$ & $0.112^{*}$ & $0.072^{*}$ & $0.326^{*}$ & $0.249^{*}$ & $-0.181^{*}$ \\
12: Firmsize & $0.411^{*}$ & $0.424^{*}$ & $0.357^{*}$ & $0.215^{*}$ & $0.276^{*}$ & $0.102^{*}$ & 0.019 & $-0.181^{*}$ \\
13: Leverage & $0.167^{*}$ & $0.125^{*}$ & $0.168^{*}$ & $0.114^{*}$ & 0.054 & $0.248^{*}$ & $0.264^{*}$ & $-0.229^{*}$ \\
14: Profitability & -0.043 & $-0.070^{*}$ & -0.059 & 0.038 & -0.058 & -0.052 & 0.021 & $0.096^{*}$ \\
15: Tobin Q & -0.047 & -0.056 & $-0.069^{*}$ & 0.019 & -0.061 & -0.021 & 0.021 & -0.032 \\
\hline Variables & $\mathbf{V 9}$ & $\mathbf{V 1 0}$ & $\mathbf{V 1 1}$ & $\mathbf{V 1 2}$ & $\mathbf{V 1 3}$ & $\mathbf{V 1 4}$ & $\mathbf{V 1 5}$ & $\mathbf{.}$ \\
\hline 9: Bsize & 1 & & & & & & & \\
10: CEOduality & $0.070^{*}$ & 1 & & & & & & \\
11: Freefperc & -0.021 & 0.021 & 1 & & & & & \\
12: Firmsize & $0.412^{*}$ & $0.200^{*}$ & 0.016 & 1 & & & & \\
13: Leverage & $0.178^{*}$ & 0.05 & $0.165^{*}$ & $0.164^{*}$ & 1 & & & \\
14: Profitability & 0.001 & -0.013 & -0.056 & $-0.250^{*}$ & -0.053 & 1 & & \\
15: Tobin Q & -0.001 & $0.101^{*}$ & -0.002 & $-0.237^{*}$ & 0.041 & $0.711^{*}$ & 1 & \\
\hline
\end{tabular}

* shows significance at the.05 level 


\section{Table 3}

Panel data analysis with fixed-effects estimator (Model 1)

\begin{tabular}{|c|c|c|c|c|}
\hline Independent variables & $\begin{array}{r}(1) \\
\text { ESGscore } \\
\end{array}$ & $\begin{array}{r}(2) \\
\text { ENVpilscore } \\
\end{array}$ & $\begin{array}{r}(3) \\
\text { SOCpilscore } \\
\end{array}$ & $\begin{array}{r}\text { (4) } \\
\text { GOVpilscore } \\
\end{array}$ \\
\hline CSRcommittee & $\begin{array}{l}11.4^{* * * *} \\
(13.15)\end{array}$ & $\begin{array}{l}14.9^{* * * *} \\
(14.07)\end{array}$ & $\begin{array}{l}11.3^{* * * *} \\
(10.06)\end{array}$ & $\begin{array}{r}7.58^{* * * *} \\
(5.19)\end{array}$ \\
\hline Bindepend & $\begin{array}{r}0.14^{* * *} \\
(3.63)\end{array}$ & $\begin{array}{r}-0.0035 \\
(-0.07)\end{array}$ & $\begin{array}{l}0.076 \\
(1.53)\end{array}$ & $\begin{array}{r}0.37^{* * *} \\
(5.76)\end{array}$ \\
\hline Bdiversity & $\begin{array}{r}0.32^{* * *} \\
(8.78)\end{array}$ & $\begin{array}{r}0.24^{* * *} \\
(5.31)\end{array}$ & $\begin{array}{r}0.24^{* * *} \\
(5.02)\end{array}$ & $\begin{array}{r}0.51^{* * * *} \\
(8.30)\end{array}$ \\
\hline Bdiligence & $\begin{array}{l}0.12^{* *} \\
(2.34)\end{array}$ & $\begin{array}{l}0.021 \\
(0.35)\end{array}$ & $\begin{array}{l}0.13^{* *} \\
(1.97)\end{array}$ & $\begin{array}{l}0.21^{* *} \\
(2.51)\end{array}$ \\
\hline Bsize & $\begin{array}{l}-0.42^{* *} \\
(-2.16)\end{array}$ & $\begin{array}{l}-0.064 \\
(-0.27)\end{array}$ & $\begin{array}{r}-0.39 \\
(-1.56)\end{array}$ & $\begin{array}{l}-0.85^{* *} \\
(-2.58)\end{array}$ \\
\hline CEOduality & $\begin{array}{r}-1.78 \\
(-1.46)\end{array}$ & $\begin{array}{r}-0.52 \\
(-0.35)\end{array}$ & $\begin{array}{r}-2.31 \\
(-1.46)\end{array}$ & $\begin{array}{r}-2.59 \\
(-1.26)\end{array}$ \\
\hline Freefperc & $\begin{array}{l}0.053 \\
(1.59)\end{array}$ & $\begin{array}{l}-0.012 \\
(-0.30)\end{array}$ & $\begin{array}{l}0.052 \\
(1.22)\end{array}$ & $\begin{array}{l}0.13^{* *} \\
(2.25)\end{array}$ \\
\hline Firmsize & $\begin{array}{r}2.42^{* * *} \\
(3.12)\end{array}$ & $\begin{array}{r}4.33^{* * *} \\
(4.56)\end{array}$ & $\begin{array}{r}3.29^{* * *} \\
(3.28)\end{array}$ & $\begin{array}{r}-0.72 \\
(-0.55)\end{array}$ \\
\hline Leverage & $\begin{array}{r}0.085^{* * *} \\
(3.18)\end{array}$ & $\begin{array}{r}0.18^{* * *} \\
(5.48)\end{array}$ & $\begin{array}{l}0.015 \\
(0.44)\end{array}$ & $\begin{array}{l}0.061 \\
(1.36)\end{array}$ \\
\hline Profitability & $\begin{array}{r}-0.16^{* * *} \\
(-3.03)\end{array}$ & $\begin{array}{l}-0.032 \\
(-0.50)\end{array}$ & $\begin{array}{r}-0.24^{* * * *} \\
(-3.51)\end{array}$ & $\begin{array}{l}-0.21^{* *} \\
(-2.35)\end{array}$ \\
\hline Constant & $\begin{array}{l}-36.9^{* *} \\
(-2.11)\end{array}$ & $\begin{array}{r}-64.5^{* * *} \\
(-3.01)\end{array}$ & $\begin{array}{l}-44.1^{*} \\
(-1.94)\end{array}$ & $\begin{array}{r}2.06 \\
(0.07) \\
\end{array}$ \\
\hline Firm-year effect & Yes & Yes & Yes & Yes \\
\hline $\mathrm{N}$ & 920 & 920 & 920 & 920 \\
\hline Adj. $R^{2}$ & 0.45 & 0.43 & 0.24 & 0.07 \\
\hline F-Stat & $55.85^{* * *}$ & $51.88^{* * * *}$ & $27.77^{* * *}$ & $15.03^{* * *}$ \\
\hline
\end{tabular}

t statistics in parentheses; ${ }^{*} p<0.10,{ }^{* *} p<0.05,{ }^{* * *} p<0.01$ 


\section{Table 4}

Panel data analysis with fixed effects estimator (Model 2)

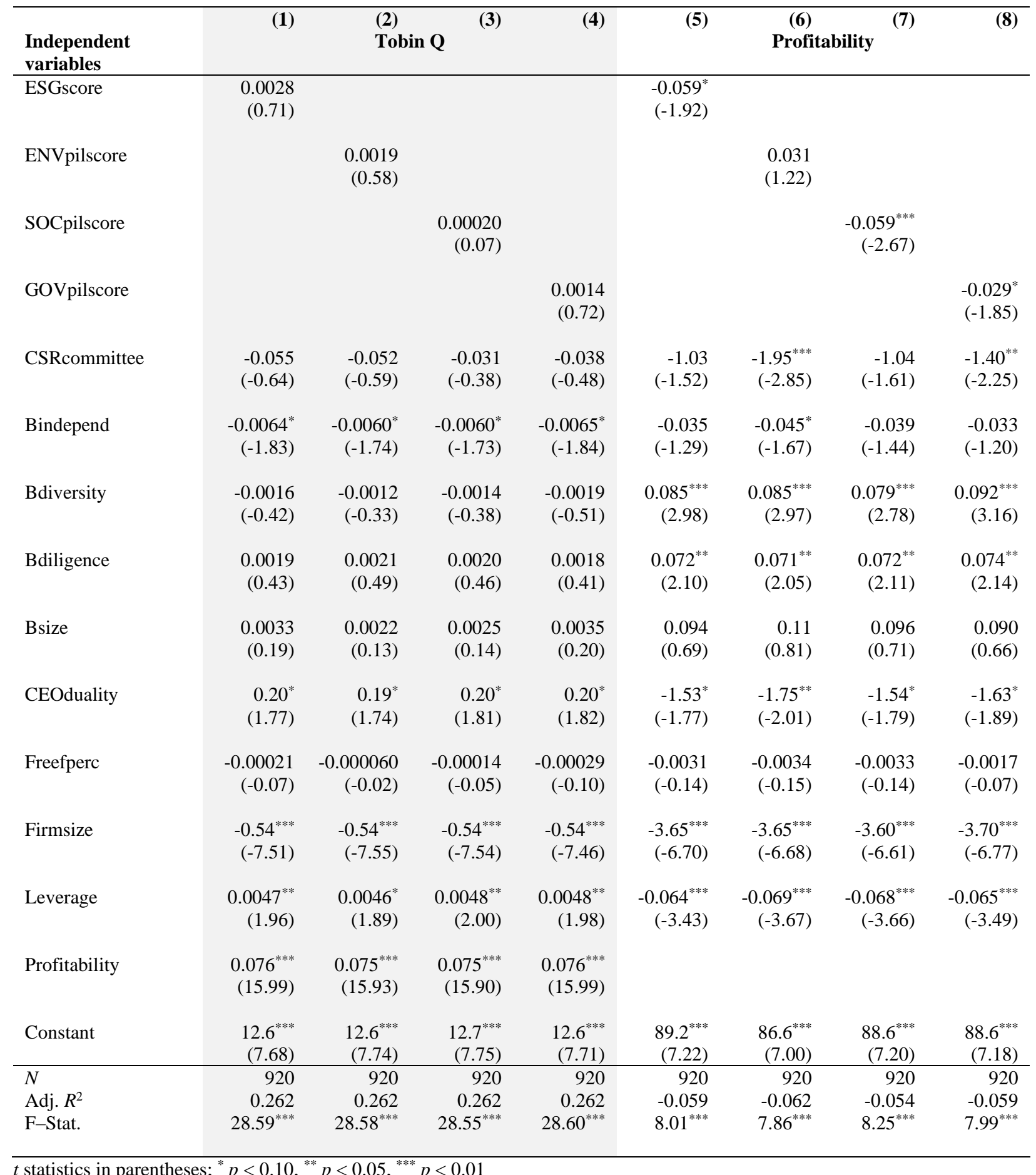

$t$ statistics in parentheses; ${ }^{*} p<0.10,{ }^{* * *} p<0.05,{ }^{* * * *} p<0.01$ 


\section{Table 5}

Robustness check for Model 1 using OLS

\begin{tabular}{|c|c|c|c|c|}
\hline Indenendent variables & $\begin{array}{r}\text { (1) } \\
\text { ESGscore }\end{array}$ & $\begin{array}{r}(2) \\
\text { FNVnilscore }\end{array}$ & $\begin{array}{r}\text { (3) } \\
\text { SOCnilscore }\end{array}$ & $\begin{array}{r}\text { (4) } \\
\text { GOVpilscore }\end{array}$ \\
\hline CSRcommittee & $\begin{array}{c}17.8^{* * *} \\
(22.36)\end{array}$ & $\begin{array}{l}22.4^{* * *} \\
(21.67)\end{array}$ & $\begin{array}{c}20.3^{* * *} \\
(18.25)\end{array}$ & $\begin{array}{r}9.63^{* * *} \\
(7.38)\end{array}$ \\
\hline Bindepend & $\begin{array}{c}0.16^{* * *} \\
(6.80)\end{array}$ & $\begin{array}{c}0.12^{* * * *} \\
(3.89)\end{array}$ & $\begin{array}{c}0.31^{* * *} \\
(9.13)\end{array}$ & $\begin{array}{l}0.042 \\
(1.07)\end{array}$ \\
\hline Bdiversity & $\begin{array}{l}0.32^{* * *} \\
(10.22)\end{array}$ & $\begin{array}{c}0.23^{* * *} \\
(5.80)\end{array}$ & $\begin{array}{c}0.26^{* * *} \\
(5.90)\end{array}$ & $\begin{array}{r}0.48^{* * * *} \\
(9.43)\end{array}$ \\
\hline Bdiligence & $\begin{array}{c}0.24^{* * *} \\
(6.20)\end{array}$ & $\begin{array}{c}0.28^{* * *} \\
(5.54)\end{array}$ & $\begin{array}{c}0.19^{* * *} \\
(3.54)\end{array}$ & $\begin{array}{r}0.25^{* * *} \\
(3.96)\end{array}$ \\
\hline Bsize & $\begin{array}{c}0.29^{*} \\
(1.92)\end{array}$ & $\begin{array}{c}0.78^{* * *} \\
(3.91)\end{array}$ & $\begin{array}{l}0.54^{* *} \\
(2.52)\end{array}$ & $\begin{array}{l}-0.54^{* *} \\
(-2.14)\end{array}$ \\
\hline CEOduality & $\begin{array}{r}0.39 \\
(0.52)\end{array}$ & $\begin{array}{c}4.17^{* * *} \\
(4.19)\end{array}$ & $\begin{array}{c}-4.52^{* * *} \\
(-4.22)\end{array}$ & $\begin{array}{r}1.91 \\
(1.53)\end{array}$ \\
\hline Freefperc & $\begin{array}{l}0.032^{*} \\
(1.93)\end{array}$ & $\begin{array}{r}0.0087 \\
(0.41)\end{array}$ & $\begin{array}{r}0.060^{* * * *} \\
(2.60)\end{array}$ & $\begin{array}{l}0.025 \\
(0.91)\end{array}$ \\
\hline Firmsize & $\begin{array}{c}3.21^{* * *} \\
(10.99)\end{array}$ & $\begin{array}{c}3.41^{* * *} \\
(8.97)\end{array}$ & $\begin{array}{c}3.34^{* * *} \\
(8.17)\end{array}$ & $\begin{array}{r}2.83^{* * *} \\
(5.91)\end{array}$ \\
\hline Leverage & $\begin{array}{r}0.0058 \\
(0.37)\end{array}$ & $\begin{array}{r}0.0088 \\
(0.42)\end{array}$ & $\begin{array}{r}-0.0026 \\
(-0.12)\end{array}$ & $\begin{array}{l}0.012 \\
(0.47)\end{array}$ \\
\hline Profitability & $\begin{array}{l}0.11^{* *} \\
(2.18)\end{array}$ & $\begin{array}{r}0.027 \\
(0.41)\end{array}$ & $\begin{array}{r}0.075 \\
(1.05)\end{array}$ & $\begin{array}{r}0.25^{* * *} \\
(2.96)\end{array}$ \\
\hline Constant & $\begin{array}{c}-72.7^{* * *} \\
(-9.55)\end{array}$ & $\begin{array}{c}-81.3^{* * *} \\
(-8.20)\end{array}$ & $\begin{array}{c}-81.7^{* * *} \\
(-7.66)\end{array}$ & $\begin{array}{c}-52.6^{* * *} \\
(-4.21)\end{array}$ \\
\hline $\mathrm{N}$ & 920 & 920 & 920 & 920 \\
\hline Adj. $\mathrm{R}^{2}$ & 0.631 & 0.581 & 0.544 & 0.242 \\
\hline F-Stat. & $157.97^{* * *}$ & $128.69^{* * *}$ & $110.65^{* * *}$ & $30.32^{* * * *}$ \\
\hline
\end{tabular}

t statistics in parentheses; ${ }^{*} p<0.10,{ }^{* *} p<0.05,{ }^{* * *} p<0.01$ 
Table 6

Robustness check for Model 2 using OLS

\begin{tabular}{|c|c|c|c|c|c|c|c|c|}
\hline $\begin{array}{l}\text { Independent } \\
\text { Variables }\end{array}$ & \multicolumn{4}{|c|}{ Tobin Q } & \multicolumn{4}{|c|}{ Profitability } \\
\hline ESGscore & $\begin{array}{r}0.0038 \\
(1.18)\end{array}$ & & & & $\begin{array}{c}0.047^{* *} \\
(2.18)\end{array}$ & & & \\
\hline ENVpilscore & & $\begin{array}{r}0.0031 \\
(1.25)\end{array}$ & & & & $\begin{array}{r}0.0067 \\
(0.41)\end{array}$ & & \\
\hline SOCpilscore & & & $\begin{array}{r}0.0014 \\
(0.62)\end{array}$ & & & & $\begin{array}{l}0.016 \\
(1.05)\end{array}$ & \\
\hline GOVpilscore & & & & $\begin{array}{r}0.0013 \\
(0.63)\end{array}$ & & & & $\begin{array}{r}0.039^{\text {*** }} \\
(2.96)\end{array}$ \\
\hline CSRcommittee & $\begin{array}{r}-0.0082 \\
(-0.08)\end{array}$ & $\begin{array}{l}-0.010 \\
(-0.11)\end{array}$ & $\begin{array}{l}0.031 \\
(0.34)\end{array}$ & $\begin{array}{l}0.048 \\
(0.59)\end{array}$ & $\begin{array}{l}-1.48^{* *} \\
(-2.30)\end{array}$ & $\begin{array}{r}-0.80 \\
(-1.25)\end{array}$ & $\begin{array}{r}-0.97 \\
(-1.61)\end{array}$ & $\begin{array}{l}-1.01^{*} \\
(-1.91)\end{array}$ \\
\hline Bindepend & $\begin{array}{r}-0.0029 \\
(-1.22)\end{array}$ & $\begin{array}{r}-0.0027 \\
(-1.14)\end{array}$ & $\begin{array}{r}-0.0028 \\
(-1.12)\end{array}$ & $\begin{array}{r}-0.0024 \\
(-1.01)\end{array}$ & $\begin{array}{l}-0.023 \\
(-1.45)\end{array}$ & $\begin{array}{l}-0.016 \\
(-1.04)\end{array}$ & $\begin{array}{l}-0.021 \\
(-1.26)\end{array}$ & $\begin{array}{l}-0.017 \\
(-1.09)\end{array}$ \\
\hline Bdiversity & $\begin{array}{r}-0.0016 \\
(-0.49)\end{array}$ & $\begin{array}{r}-0.0011 \\
(-0.35)\end{array}$ & $\begin{array}{r}-0.00073 \\
(-0.24)\end{array}$ & $\begin{array}{r}-0.00097 \\
(-0.30)\end{array}$ & $\begin{array}{r}0.012 \\
(0.58)\end{array}$ & $\begin{array}{l}0.026 \\
(1.25)\end{array}$ & $\begin{array}{l}0.023 \\
(1.13)\end{array}$ & $\begin{array}{r}0.0086 \\
(0.41)\end{array}$ \\
\hline Bdiligence & $\begin{array}{r}-0.011^{\text {*** }} \\
(-2.82)\end{array}$ & $\begin{array}{r}-0.011^{\text {*** }} \\
(-2.82)\end{array}$ & $\begin{array}{r}-0.010^{* * * *} \\
(-2.69)\end{array}$ & $\begin{array}{r}-0.010^{\text {**** }} \\
(-2.70)\end{array}$ & $\begin{array}{c}0.044^{*} \\
(1.69)\end{array}$ & $\begin{array}{r}0.053^{* *} \\
(2.07)\end{array}$ & $\begin{array}{c}0.052^{* *} \\
(2.04)\end{array}$ & $\begin{array}{l}0.045^{*} \\
(1.77)\end{array}$ \\
\hline Bsize & $\begin{array}{r}0.0087 \\
(0.58)\end{array}$ & $\begin{array}{r}0.0074 \\
(0.49)\end{array}$ & $\begin{array}{r}0.0090 \\
(0.60)\end{array}$ & $\begin{array}{l}0.010 \\
(0.70)\end{array}$ & $\begin{array}{c}0.38^{* * * *} \\
(3.88)\end{array}$ & $\begin{array}{c}0.39^{\text {**** }} \\
(3.96)\end{array}$ & $\begin{array}{c}0.39^{* * * *} \\
(3.94)\end{array}$ & $\begin{array}{r}0.42^{* * * *} \\
(4.23)\end{array}$ \\
\hline CEOduality & $\begin{array}{c}0.32^{* * * *} \\
(4.24)\end{array}$ & $\begin{array}{c}0.31^{* * *} \\
(4.05)\end{array}$ & $\begin{array}{c}0.33^{\text {*** }} \\
(4.31)\end{array}$ & $\begin{array}{c}0.32^{* * *} \\
(4.22)\end{array}$ & $\begin{array}{l}1.04^{* *} \\
(2.09)\end{array}$ & $\begin{array}{l}1.03^{* *} \\
(2.06)\end{array}$ & $\begin{array}{l}1.13^{* *} \\
(2.26)\end{array}$ & $\begin{array}{l}0.98^{* *} \\
(1.97)\end{array}$ \\
\hline Freefperc & $\begin{array}{r}0.0013 \\
(0.77)\end{array}$ & $\begin{array}{r}0.0013 \\
(0.83)\end{array}$ & $\begin{array}{r}0.0013 \\
(0.79)\end{array}$ & $\begin{array}{r}0.0013 \\
(0.83)\end{array}$ & $\begin{array}{r}-0.0081 \\
(-0.76)\end{array}$ & $\begin{array}{r}-0.0067 \\
(-0.62)\end{array}$ & $\begin{array}{r}-0.0076 \\
(-0.71)\end{array}$ & $\begin{array}{r}-0.0076 \\
(-0.70)\end{array}$ \\
\hline Firmsize & $\begin{array}{c}-0.14^{\text {***k }} \\
(-4.60)\end{array}$ & $\begin{array}{c}-0.14^{\text {*** }} \\
(-4.64)\end{array}$ & $\begin{array}{c}-0.13^{* * *} \\
(-4.47)\end{array}$ & $\begin{array}{c}-0.13^{* * *} \\
(-4.50)\end{array}$ & $\begin{array}{c}-1.58^{* * * *} \\
(-8.10)\end{array}$ & $\begin{array}{c}-1.46^{\text {**** }} \\
(-7.58)\end{array}$ & $\begin{array}{c}-1.49^{* * *} \\
(-7.80)\end{array}$ & $\begin{array}{r}-1.53^{* * *} \\
(-8.23)\end{array}$ \\
\hline Leverage & $\begin{array}{r}0.0037^{* *} \\
(2.37)\end{array}$ & $\begin{array}{r}0.0037^{* *} \\
(2.37)\end{array}$ & $\begin{array}{r}0.0037^{* *} \\
(2.39)\end{array}$ & $\begin{array}{r}0.0037^{* *} \\
(2.38)\end{array}$ & $\begin{array}{c}-0.018^{*} \\
(-1.71)\end{array}$ & $\begin{array}{c}-0.017^{*} \\
(-1.69)\end{array}$ & $\begin{array}{c}-0.017^{*} \\
(-1.68)\end{array}$ & $\begin{array}{c}-0.018^{*} \\
(-1.73)\end{array}$ \\
\hline Profitability & $\begin{array}{c}0.15^{* * * *} \\
(29.19)\end{array}$ & $\begin{array}{c}0.15^{\text {*** }} \\
(29.33)\end{array}$ & $\begin{array}{c}0.15^{\text {**** }} \\
(29.29)\end{array}$ & $\begin{array}{c}0.15^{\text {**** }} \\
(29.13)\end{array}$ & & & & \\
\hline Constant & $\begin{array}{c}4.38^{* * *} \\
(5.60) \\
\end{array}$ & $\begin{array}{c}4.36^{* * * *} \\
(5.63) \\
\end{array}$ & $\begin{array}{c}4.22^{* * *} \\
(5.48)\end{array}$ & $\begin{array}{c}4.17^{\text {**** }} \\
(5.53)\end{array}$ & $\begin{array}{c}34.8^{* * * *} \\
(6.88)\end{array}$ & $\begin{array}{c}32.1^{\text {**** }} \\
(6.39)\end{array}$ & $\begin{array}{c}32.9^{* * * *} \\
(6.58)\end{array}$ & $\begin{array}{c}33.3^{\text {*** }} \\
(6.85)\end{array}$ \\
\hline$N$ & 920 & 920 & 920 & 920 & 920 & 920 & 920 & 920 \\
\hline Adj. $R^{2}$ & 0.530 & 0.530 & 0.529 & 0.529 & 0.086 & 0.082 & 0.082 & 0.090 \\
\hline F-Stat. & 95.15 & 95.19 & 94.96 & 94.96 & 9.66 & 9.15 & 9.26 & 10.10 \\
\hline
\end{tabular}

